OPEN ACCESS

Edited by:

Brian J. Palik,

USDA Forest Service, United States

Reviewed by:

Dario Martin-Benito,

Centro de Investigación Forestal

(INIA), Spain

Flurin Babst,

Władysław Szafer Institute of Botany

(PAN), Poland

*Correspondence:

Karolina Janecka

karolinaejanecka@gmail.com

Specialty section:

This article was submitted to Temperate and Boreal Forests,

a section of the journal

Frontiers in Forests and Global

Change

Received: 01 July 2020

Accepted: 24 August 2020

Published: 17 September 2020

Citation:

Janecka K, Harvey JE, Trouillier M, Kaczka RJ, Metslaid S, Metslaid M,

Buras A and Wilmking M (2020)

Higher Winter-Spring Temperature and Winter-Spring/Summer Moisture

Availability Increase Scots Pine Growth on Coastal Dune Microsites

Around the South Baltic Sea.

Front. For. Glob. Change 3:578912.

doi: 10.3389/ffgc.2020.578912

\section{Higher Winter-Spring Temperature and Winter-Spring/Summer Moisture Availability Increase Scots Pine Growth on Coastal Dune Microsites Around the South Baltic Sea}

\author{
Karolina Janecka ${ }^{1 *}$, Jill E. Harvey 1,2, Mario Trouillier', Ryszard J. Kaczka ${ }^{3,4}$, \\ Sandra Metslaid ${ }^{5}$, Marek Metslaid ${ }^{5}$, Allan Buras ${ }^{6}$ and Martin Wilmking ${ }^{1}$
}

${ }^{1}$ Institute of Botany and Landscape Ecology, University of Greifswald, Greifswald, Germany, ${ }^{2}$ Natural Resources Canada, Canadian Forest Service, Northern Forestry Centre, Edmonton, AB, Canada, ${ }^{3}$ Faculty of Natural Sciences, University of Silesia, Sosnowiec, Poland, ${ }^{4}$ Department of Biology, University of Hradec Králové, Hradec Králové, Czechia, ${ }^{5}$ Institute of Forestry and Rural Engineering, Estonian University of Life Sciences, Tartu, Estonia, ${ }^{6}$ Department of Ecology and Ecosystem Management, Technical University of Munich, Freising, Germany

Coastal sand dunes near the Baltic Sea are a dynamic environment marking the boundary between land and sea and oftentimes covered by Scots pine (Pinus sylvestris L.) forests. Complex climate-environmental interactions characterize these ecosystems and largely determine the productivity and state of these coastal forests. In the face of future climate change, understanding interactions between coastal tree growth and climate variability is important to promote sustainable coastal forests. In this study, we assessed the effect of microsite conditions on tree growth and the temporal and spatial variability of the relationship between climate and Scots pine growth at nine coastal sand dune sites located around the south Baltic Sea. At each site, we studied the growth of Scots pine growing at microsites located at the ridge and bottom of a dune and built a network of 18 ring-width and 18 latewood blue intensity chronologies. Across this network, we found that microsite has a minor influence on ring-width variability, basal area increment, latewood blue intensity, and climate sensitivity. However, at the local scale, microsite effects turned out to be important for growth and climate sensitivity at some sites. Correlation analysis indicated that the strength and direction of climate-growth responses for the ring-width and blue intensity chronologies were similar for climate variables over the 1903-2016 period. A strong and positive relationship between ring-width and latewood blue intensity chronologies with winter-spring temperature was detected at local and regional scales. We identified a relatively strong, positive influence of winter-spring/summer moisture availability on both tree-ring proxies. When climate-growth responses between two intervals (19031959, 1960-2016) were compared, the strength of growth responses to temperature and moisture availability for both proxies varied. More specifically, for the ring-width network, we identified decreasing temperature-growth responses, which is in contrast to the latewood blue intensity network, where we documented decreasing and increasing 
temperature-growth relationships in the north and south respectively. We conclude that coastal Scots pine forests are primarily limited by winter-spring temperature and winterspring/summer drought despite differing microsite conditions. We detected some spatial and temporal variability in climate-growth relationships that warrant further investigation.

Keywords: ring-width, blue intensity, climate-growth relationship, temporal variability, coastal dunes, microsite, Europe, climate change

\section{INTRODUCTION}

Annual mean air temperature for land-surfaces surrounding the Baltic Sea has increased since the beginning of instrumental records in 1871 (von Storch et al., 2015). The largest increase in air temperature was observed for winter months, with higher temperatures reported in Germany (Bormann, 2010), Poland (Kozuchowski and Degirmendzic, 2005), the Baltic States (Lithuania: Bukantis and Rimkus, 2005; Latvia: Draveniece, 2009; Estonia: Jaagus, 2006), Finland (Mikkonen et al., 2015), and Sweden (Räisänen and Alexandersson, 2003), especially in the second half of the 20th century. The interplay between rising temperatures, changes in spatial and temporal precipitation patterns, and the number and intensity of extreme climate events (HELCOM, 2013; von Storch et al., 2015), influences forest vegetation and productivity (McCarthy et al., 2001; Boisvenue and Running, 2006; Parry et al., 2007; Kreyling, 2010; Lindner et al., 2010). To better understand how recent climate change affects forest ecosystems, new approaches to document the interaction between tree growth and climate variability are needed. For example, different tree-ring parameters (e.g., ringwidth - RW, maximum latewood density - MXD, blue intensity BI, including latewood and earlywood blue intensity - LBI and EBI, respectively) can be used in climate-growth analyses to assess the effects of past and ongoing climate change on tree growth over time and space (Babst et al., 2013, 2018, 2019; Wilson et al., 2017; Harvey et al., 2020).

Scots pine (Pinus sylvestris L.) is a widely distributed conifer species in Eurasia and can grow in a variety of ecological and climatic conditions. A high tolerance to poor soils, droughts and frost events makes Scots pine the desired species for windbreak plantations (Brown and Schwemler, 1990) within coastal areas, in land reclamation treatments (Metslaid et al., 2016), and for anti-erosion purposes (Koprowski et al., 2010). In boreal forests of northern Europe, summer temperature is frequently reported as the primary limiting factor of Scots pine growth (RW and MXD: Schweingruber et al., 1988; Düthorn et al., 2013, 2015; Lindholm et al., 2014; Lange et al., 2018; BI: McCarroll et al., 2002; Björklund et al., 2014). In the central part of the species distribution in Europe, i.e., in a transition zone from boreal to temperate forests and toward the south of its distributional range, winter or winter-spring temperatures mainly and positively influence Scots pine growth (RW: Pärn, 2002; Hordo et al., 2011; Balanzategui et al., 2018; Metslaid et al., 2018; Matisons et al., 2019; Harvey et al., 2020; EBI: Seftigen et al., 2020). In addition to temperature, moisture availability has also been documented as a growth-limiting factor (RW: Helama and Lindholm, 2003; Vitas, 2004, 2006;
Erlickyte and Vitas, 2008; Drobyshev et al., 2011; Düthorn et al., 2013; Bose et al., 2020; RW and EBI: Seftigen et al., 2020). At the southern distribution margin, plant water availability (RW: Bogino et al., 2009; Buras et al., 2018a), precipitation (RW: Sánchez-Salguero et al., 2015a), and winter, spring, or summer temperatures (RW: Herrero et al., 2013; Sánchez-Salguero et al., 2015a,b) modulate Scots pine growth.

At latitudes above $50^{\circ} \mathrm{N}$, strong positive relationships between climate and Scots pine tree-ring datasets have resulted in skillful, tree-ring based climate reconstructions (temperature: Gouirand et al., 2008; Gunnarson et al., 2011; Seftigen et al., 2020; precipitation: Linderholm and Chen, 2005; Seftigen et al., 2020; and drought: Jönsson and Nilsson, 2009; Seftigen et al., 2013). However, the climate-growth responses of Scots pine in boreal, hemiboreal, and temperate forests are variable in space and time. In these forest types, especially in hemiboreal and temperate forests, local climate and microsite conditions are thought to influence climate-growth responses (boreal: Linderholm et al., 2014; Düthorn et al., 2016; hemiboreal and temperate: Pärn, 2002; Mandre et al., 2010; Cedro and Lamentowicz, 2011; Hordo et al., 2011; Metslaid et al., 2018). A recent study conducted across Eurasia at the northern distribution limit of Scots pine, revealed climatic regimes override microsite effects on climate sensitivity, though microsite determined absolute growth and caused microsite-specific growth variability (Lange et al., 2018). Further, longer term trends in climate change (e.g., 20th century climate warming) have been found to influence climate-growth relationships for multiple conifer species in Central Europe, leading to changing climate-growth responses over time (Scots pine: Pärn, 2009; Düthorn et al., 2016; Kaczka et al., 2016; Metslaid et al., 2018; Harvey et al., 2020; Seftigen et al., 2020; Norway spruce (Picea abies L. Karst): Kaczka et al., 2016; Buras et al., 2018b, Swiss stone pine (Pinus cembra L.): Kaczka et al., 2016).

Coastal dune forests are an important ecosystem that minimizes coastal erosion and wind, hinders the deleterious effects of salt spray and protects inland areas from coastal water intrusion (Ratas and Rivis, 2003; Łabuz, 2013). Previous studies on Scots pine growth on costal dunes in the south Baltic Sea region documented several stress factors acting simultaneously on tree growth, where water and nutrient shortages were the most important factors in constricting tree growth (Mandre et al., 2010). The amount of water and nutrients in the soil decreases with elevation on the dune, resulting in substantial physiological stress for tree functioning, especially on the dune ridge. Apart from low water and nutrient availability on the ridge, periodic drought events are likely to occur due to low water holding capacity of sand, wind and sun exposure 
(Mandre et al., 2008, 2010; Maun, 2009). In contrast to the ridge, soil at the bottom of dunes is richer in nutrients. This is a result of surface runoff and groundwater flow from the dune that washes nutrients from the upper toward the lower parts of the dune and the decomposition of plant organic matter that accumulates at the bottom of the dune (Mandre et al., 2008, 2010). Although the soil at the bottom of the dune is generally more nutrient rich, excessive moisture in the soil can, at least temporarily, limit the oxygen uptake necessary for tree growth (Mandre et al., 2010). Recent studies conducted at a local scale in Estonia (Örd, 1972; Pärn, 2002, 2008; Mandre et al., 2010) reported differing microsite conditions at the dune ridge and at the bottom as important factors influencing Scots pine growth and climate-growth responses in this part of the Baltic Sea.

In this study, we examine the effect of microsite conditions on growth and the temporal and spatial climate-growth responses of Scots pine from the coastal sand dune sites located around the south Baltic Sea. We constructed well-replicated, micrositebased RW and LBI chronologies. We used these datasets to: (i) investigate the similarity of growth pattern(s) across our treering network, (ii) identify dominant climate-growth responses at the microsite and regional scales, (iii) test the stationarity of growth responses over time, and (iv) assess whether microsite (dune ridge vs. bottom) has an effect on growth patterns and climate-growth relationships.

\section{MATERIALS AND METHODS}

\section{Study Area and Sampling Design}

Our study includes coastal areas surrounding the south Baltic Sea from the Gulf of Finland, through the Gotland Basin to the Arkona Basin (Figure 1). We selected nine sampling sites located in coastal dune settings (Figure 1) where dune height and morphology vary from typical peaked dune shapes (ridge) with the height between $\sim 10$ to $40 \mathrm{~m}$ asl to moderately undulating terrain with relative height (i.e., a measure of the height of a dune ridge to the dune bottom) ranging from $\sim 0.5$ to $10 \mathrm{~m}$. These nine sites were selected based on the presence of sandy dunes, age of trees ( $>100$ years), accessibility, and sampling permission, and all were located between 0.2 and $2 \mathrm{~km}$ from the Baltic Sea. At each site, we chose two contrasting sub-sites which we term "microsites": (i) dune ridge and (ii) bottom of this dune. At all sites, both types of microsites were characterized by sandy soil (Podzol), but differed in ground vegetation cover. The ridge microsites were mainly vegetated by Cladonia sp., the bottom microsites by Calluna sp. or Vaccinum uliginosum sp. (Table 1). All sites were classified as managed, either in the past (GS, DA) or more recently (UA, UB, GA, GB, TP, NO, VO). In total, the study is based on 18 microsites from nine dune sites located around the south Baltic Sea (Figure 1).

At each microsite, we sampled two $5 \mathrm{~mm}$ increment cores per tree at breast height taken perpendicularly to account for possibly occurring compression wood (Janecka and Kaczka, 2016; Janecka et al., 2016, 2020). In total, 768 trees were sampled (32-66 trees per microsite). For each tree, diameter at breast height $(\mathrm{DBH})$

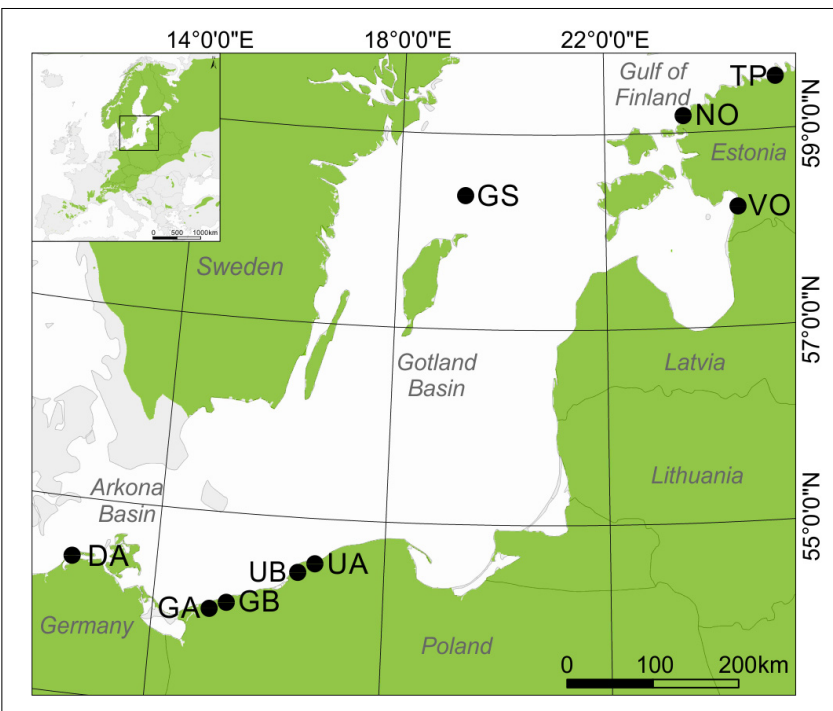

FIGURE 1 | The location of sampling sites around the south Baltic Sea. A small map shows the location of study area and green shading presents Scots pine distribution (www.euforgen.org/species/). Site name abbreviations are explained in Table $\mathbf{1 .}$

and tree height were recorded using a clinometer (Suunto; at the sites: DA, UA, UB, GA, GB, GS) and Vertex measuring system (Haglöf; at the sites: TP, NO, VO). Additionally, we measured humus (organic) layer depth at 10 randomly located places at each microsite (Table 2).

\section{Tree-Ring Data and Chronology Development}

We applied standard dendrochronological techniques to prepare samples and measure two tree-ring proxies: RW (Speer, 2010; Schweingruber, 2012) and BI (Campbell et al., 2011; Rydval et al., 2014; Wilson et al., 2014; Kaczka et al., 2018; Björklund et al., 2019). The measurement of BI requires the extraction of resin and other soluble compounds, thus we treated all cores with ethanol in a Soxhlet apparatus for 48 h (Rydval et al., 2014; Kaczka et al., 2018; Björklund et al., 2019).

We scanned all samples at a resolution of $2400 \mathrm{dpi}$ in RGB mode using a flatbed Epson Perfection V700 scanner. The scanner was ICC calibrated using the IT8 Calibration Target (IT8.7/2) printed on Kodak Professional Endura paper with software SilverFast Ai Studio 8.0 (LaserSoft Imaging Incorporated).

We simultaneously measured two different tree-ring parameters, RW and LBI on the scanned images using CooRecorder v. 8.0 (Larsson, 2003). Previous research suggests LBI is an economical surrogate of MXD (Björklund et al., 2014; Rydval et al., 2014; Wilson et al., 2014) that is particularly skillful in characterizing past temperature variability, especially in boreal and temperate Scots pine and Norway spruce tree rings (Björklund et al., 2014; Rydval et al., 2014; Kaczka et al., 2018; Seftigen et al., 2020). The LBI data was generated in a dedicated BI mode of the software (Rydval et al., 2014), with adjusted 
TABLE 1 | Description of the study sites (the last letter in the code of microsite type refers to the ridge (R) and bottom (B) of the dune), number of analyzed trees ( $N$ : RW - ring-width, LBI - latewood blue intensity) and forest site type (CL - Cladonia, CA - Calluna, VU - Vaccinum uliginosum).

\begin{tabular}{|c|c|c|c|c|c|c|c|}
\hline \multirow[t]{2}{*}{ Country } & \multirow[t]{2}{*}{ Site } & \multirow[t]{2}{*}{ Microsite type } & \multirow[t]{2}{*}{ Latitude } & \multirow[t]{2}{*}{ Longitude } & \multicolumn{2}{|c|}{$\mathbf{N}$} & \multirow[t]{2}{*}{ Forest site type } \\
\hline & & & & & RW & LBI & \\
\hline \multirow[t]{6}{*}{ Estonia } & Võiste (VO) & ridge (VOR) & $58.204^{\circ}$ & $24.498^{\circ}$ & 50 & 47 & $\mathrm{CL}$ \\
\hline & & bottom (VOB) & $58.201^{\circ}$ & $24.495^{\circ}$ & 49 & 36 & VU \\
\hline & Tapurla (TP) & ridge (TPR) & $59.606^{\circ}$ & $25.551^{\circ}$ & 47 & 44 & $\mathrm{CL}$ \\
\hline & & bottom (TPB) & $59.594^{\circ}$ & $25.554^{\circ}$ & 50 & 48 & VU \\
\hline & Nõva (NO) & ridge (NOR) & $59.220^{\circ}$ & $23.613^{\circ}$ & 50 & 43 & $\mathrm{CL}$ \\
\hline & & bottom (NOB) & $59.218^{\circ}$ & $23.628^{\circ}$ & 43 & 39 & VU \\
\hline \multirow[t]{2}{*}{ Sweden } & Gotska Sandön (GS) & ridge (GSR) & $58.375^{\circ}$ & $19.209^{\circ}$ & 64 & 52 & $\mathrm{CL}$ \\
\hline & & bottom (GSB) & $58.385^{\circ}$ & $19.200^{\circ}$ & 43 & 40 & CA \\
\hline \multirow[t]{8}{*}{ Poland } & Ustka (UB) & ridge (UBR) & $54.560^{\circ}$ & $16.730^{\circ}$ & 29 & 27 & $\mathrm{CL}$ \\
\hline & & bottom (UBB) & $54.560^{\circ}$ & $16.732^{\circ}$ & 32 & 30 & CA \\
\hline & Ustka (UA) & ridge (UAR) & $54.589^{\circ}$ & $16.892^{\circ}$ & 28 & 21 & $\mathrm{CL}$ \\
\hline & & bottom (UAB) & $54.563^{\circ}$ & $16.727^{\circ}$ & 35 & 35 & CA \\
\hline & Gryfice (GB) & ridge (GBR) & $54.117^{\circ}$ & $15.200^{\circ}$ & 35 & 34 & $\mathrm{CL}$ \\
\hline & & bottom (GBB) & $54.119^{\circ}$ & $15.203^{\circ}$ & 35 & 34 & CA \\
\hline & Gryfice (GA) & ridge (GAR) & $54.117^{\circ}$ & $15.208^{\circ}$ & 36 & 33 & $\mathrm{CL}$ \\
\hline & & bottom (GAB) & $54.118^{\circ}$ & $15.209^{\circ}$ & 34 & 34 & CA \\
\hline \multirow[t]{3}{*}{ Germany } & Darss (DA) & ridge (DAR) & $54.451^{\circ}$ & $12.550^{\circ}$ & 45 & 15 & $\mathrm{CL}$ \\
\hline & & bottom (DAB) & $54.451^{\circ}$ & $12.550^{\circ}$ & 22 & 14 & CA \\
\hline & & & & Total & 727 & 626 & \\
\hline
\end{tabular}

parameters (width $>100$, offset $>0.4$, depth $>200$, and $30 \%$ of latewood). All RW and LBI series were visually and statistically cross-dated with CDendro (Larsson, 2003) and COFECHA (Holmes, 1985), respectively.

After cross-dating all tree-ring series, $727 \mathrm{RW}$ and 626 LBI series were standardized ( $d p l R$ package in R; Bunn, 2008) by applying a 30-year cubic smoothing spline with a 50\% frequency cut-off to remove age-related trends but also pulses related to disturbances caused by non-climatic factors that occur in the closed-forest canopy (Cook and Peters, 1981; Helama et al., 2004). Tree-ring indices were calculated via division in order to correct for heteroscedastic variances observed in tree-ring series (Cook et al., 1990; Helama et al., 2004). The use of a 30-year cubic spline detrending method ensures that RW and LBI chronologies preserve a strong year-to-year signal while all other potential long-term trends have been removed. Some RW and LBI tree-ring series were excluded from the analyses if low synchronicity with other RW or LBI tree-ring series and/or discoloration of wood surface (only in case of LBI; Rydval et al., 2014) was detected. All treering chronologies were prewhitened to remove autocorrelation and averaged into $18 \mathrm{RW}$ and $18 \mathrm{LBI}$ microsite chronologies using the biweight robust mean. Descriptive statistics, including expressed population signal (EPS; Wigley et al., 1984; Buras, 2017), mean inter-series correlation (Rbar), and Gleichlaeufigkeit (GLK) were calculated for each microsite chronology and both tree-ring proxies over the common 1903-2016 period. Lastly, we calculated the basal area increment (BAI) with the bai.out function ( $d p l R$ package in R; Bunn, 2008) from RW and stemdiameter measurements, which we corrected for bark thickness according to Pretzsch (2009).

\section{Climate Data}

Although instrumental climate data was available for each site, site-specific gridded $\left(0.5^{\circ} \times 0.5^{\circ}\right)$ monthly temperature means, precipitation sums and self-calibrated Palmer drought severity index (PDSI; a measurement of relative dryness based on recent precipitation and temperature) from CRU TS4.03 datasets were obtained (Harris et al., 2014). The available instrumental data is not complete (i.e., missing data points for particular years; Estonia) as well as varies in length (shortest series, Poland: 19502000), which would have restricted our interval for analysis to 50 years. Thus, considering strong correlations $(r=0.94-$ 0.99, for the common 1950-2000 period; not shown) between instrumental and gridded data at multiple sites in the study region, longer time series and more variable options of the gridded data product, the CRU dataset was selected for use in the climate-growth analysis.

\section{Statistical Analyses}

To assess the similarity between RW and LBI pattern(s) across our tree-ring network, we performed hierarchical cluster analysis (HCA; hclust package in R; Murtagh and Legendre, 2014) and correlation analysis (corrplot package in R; Wei et al., 2017) by using residual chronologies. For the HCA, we employed Ward's method, using the Pearson's correlation coefficient as the similarity measure between chronologies (Murtagh and Legendre, 2014). Using the visual assessment of the dendrograms, we partitioned the RW and LBI chronologies into two subregions based on a k-means approach (Pederson et al., 2020).

To determine the relationships between climate, RW, and LBI microsite chronologies, we calculated bootstrapped 
TABLE 2 | The tree metadata (average: age, tree height, diameter at the breast height - $\mathrm{DBH}$, ring-width - RW, basal area increment - BAl, and organic layer) per microsite.

\begin{tabular}{|c|c|c|c|c|c|c|c|}
\hline Country & Microsite & $\begin{array}{c}\text { Age } \\
\text { (years) }\end{array}$ & $\begin{array}{c}\text { Tree } \\
\text { height }(\mathrm{m})\end{array}$ & $\begin{array}{l}\text { DBH } \\
(\mathrm{cm})\end{array}$ & $\begin{array}{c}\mathrm{RW} \\
(\mathrm{mm})\end{array}$ & $\begin{array}{c}\text { BAl } \\
\left(\mathrm{mm}^{2}\right)\end{array}$ & $\begin{array}{c}\text { Organic } \\
\text { layer (cm) }\end{array}$ \\
\hline \multirow[t]{6}{*}{ Estonia } & VOR & $187^{\star}$ & 22.7 & 38.1 & $0.58^{\star \star \star}$ & 544.2 & $12.4^{\star \star \star}$ \\
\hline & VOB & $182^{*}$ & 23.4 & 36.4 & $0.60^{\star \star \star}$ & 522.7 & $27.2^{\star \star \star}$ \\
\hline & TPR & $149^{\star \star}$ & $19.2^{\star \star \star}$ & 34.1 & $0.56^{\star \star \star}$ & $464.9^{\star \star \star}$ & $7^{\star \star \star}$ \\
\hline & TPB & $138^{\star \star}$ & $28.5^{\star \star \star}$ & 35.5 & $0.76^{\star \star \star}$ & $608.7^{\star \star \star}$ & $11.9^{\star \star \star}$ \\
\hline & NOR & 181 & $15.8^{\star \star \star}$ & 30.3 & $0.46^{\star \star \star}$ & $344.2^{\star \star \star}$ & $5.5^{\star \star \star}$ \\
\hline & NOB & 176 & $13.3^{\star \star \star}$ & 31.1 & $0.51^{\star \star \star}$ & $406.8^{\star \star \star}$ & $11.5^{\star \star \star}$ \\
\hline \multirow[t]{2}{*}{ Sweden } & GSR & $228^{\star \star}$ & $17.2^{\star \star}$ & $44.1^{\star \star \star}$ & $0.57^{\star \star}$ & $621.6^{\star \star \star}$ & $5.1^{\star \star}$ \\
\hline & GSB & $183^{\star \star}$ & $15.3^{\star \star}$ & $32.8^{\star \star \star}$ & $0.57^{\star \star}$ & $425.1^{\star \star \star}$ & $10.2^{\star \star}$ \\
\hline \multirow[t]{8}{*}{ Poland } & UBR & $137^{\star \star}$ & $14.7^{\star}$ & 36.9 & $0.81^{\star \star \star}$ & 674.1 & $10^{\star \star}$ \\
\hline & UBB & $152^{\star \star}$ & $16.9^{\star}$ & 40.1 & $0.68^{\star \star \star}$ & 638.7 & $7.2^{\star \star}$ \\
\hline & UAR & 142 & $15.6^{\star \star \star}$ & 38.6 & $0.83^{\star \star \star}$ & 727.2 & $7.6^{\star \star \star}$ \\
\hline & UAB & 131 & $21.4^{\star \star \star}$ & 37.5 & $0.92^{\star \star \star}$ & 721.7 & $12.4^{\star \star \star}$ \\
\hline & GBR & $147^{\star \star}$ & $12.7^{\star \star \star}$ & $26.9^{\star}$ & $0.63^{\star \star \star}$ & $378.5^{\star \star \star}$ & $7.3^{\star \star \star}$ \\
\hline & GBB & $153^{\star \star}$ & $17.6^{\star \star \star}$ & $30.5^{\star}$ & $0.70^{\star \star \star}$ & $473.7^{\star \star \star}$ & $11.4^{\star \star \star}$ \\
\hline & GAR & $142^{\star \star}$ & 16.3 & 29.9 & $0.77^{\star \star}$ & $480^{\star \star \star}$ & $8.6^{\star \star \star}$ \\
\hline & GAB & $153^{\star \star}$ & 14.9 & 27.7 & $0.61^{* \star}$ & $377.3^{\star \star \star}$ & $11^{\star \star \star}$ \\
\hline \multirow[t]{2}{*}{ Germany } & DAR & 126 & 19.6 & 46.4 & $1.18^{\star \star \star} 1$ & 1028.5 & 10.1 \\
\hline & DAB & 117 & 18.4 & 38.8 & $1.14^{\star \star \star} 1$ & 1036.8 & 12.7 \\
\hline
\end{tabular}

The average RW and BAl were calculated for the 1903-2016 period that is relevant for the climate-growth analysis. Age, tree height, DBH, RW, BAl, and organic layer were tested for significant differences between mean of each pair of the ridge and bottom microsites using a Wilcoxon rank-sum test (paired test in case of RW and $B A$ I). Presented average tree age is an approximate age, i.e., calculated based on the actual number of rings. *Significantly different $(p<0.05)$. ${ }^{*}$ Significantly different $(p<0.01)$. ${ }^{* *}$ Significantly different $(p<0.001)$.

Pearson's correlation coefficients between all 36 microsite chronologies and climate variables. The significance of the correlation coefficients was tested with the bootstrapping procedure based on 1000 iterations (treeclim package in R; Zang and Biondi, 2015). Three climate variables were considered: monthly mean temperature, precipitation sums, and PDSI for (i) 13 individual months, starting from previous year September to September of the current year, (ii) for different winter (January-February), and winter-spring seasons (January-March, January-April, February-March, February-April, March-April, March-May) over the 1903-2016 period.

To gain a broad perspective of the climate-growth responses of Scots pine, we examined the spatial extent of the climategrowth (RW and LBI) responses. We performed this analysis at the sub-regional level for both tree-ring proxies using the sub-regional chronologies determined by cluster analysis and correlation matrix. First, for the spatial correlations, we selected different intervals of mean seasonal temperature and drought variables, which in the analysis of microsite climate-growth relationships showed the highest occurrence of significant scores in each sub-region and proxy. Second, we generated spatial climate correlation maps using the KNMI climate explorer in order to present the geographical extent of climate-growth responses (van Oldenborgh and Burgers, 2005; Trouet and van Oldenborgh, 2013).
To evaluate possible shifts of the climate responses of trees over time, we correlated the RW and LBI microsite and sub-regional chronologies against climate variables over two consecutive 56 years time intervals (early: 1903-1959 and recent: 1960-2016). We decided for a two-interval comparison approach as a relatively simple and effective method in detecting general changes in climate-growth relationships, which is also a common procedure for validating the temporal stability of climate-growth responses in tree-ring based climate reconstruction (Allen et al., 2018; Babst et al., 2019).

Lastly, we used linear mixed-effect models (LMM; lme4 package in R; Bates et al., 2015) to assess microsite effect (dune ridge and bottom) on Scots pine growth. In general, LMMs can be used to test the hypotheses whether a certain variable has a significant effect by comparing two models with and without this variable (Zuur et al., 2009). We used this approach to test if microsite affects absolute growth (RW, BAI, LBI) and the strength of the climate-growth relationships. Models with and without the microsite variable were compared using the Akaikes Information Criterion (AIC). We chose AIC over the Bayesian Information Criterion (BIC) following the argumentation of Burnham and Anderson (2004). In particular, we do not believe that the (quasi) true model is within our set of models and because tree growth is affected by many small, instead of a few large effects. Additionally, we calculated the marginal and the conditional $R^{2}$ (Nakagawa and Schielzeth, 2013) for all LMMs (piecewiseSEM package in $\mathrm{R}$; Lefcheck, 2016). The change in the marginal $R^{2}$ when adding the microsite variable indicates how much more/less variance was explained by this fixed effects.

Specifically, we used LMMs to answer seven questions for each site, as well as for the northern and southern sub-regions (combined sites based on the HCA and matrix correlation results).

(1) Does the microsite affect RW?

(2) Does the microsite affect BAI?

(3) Does the microsite affect LBI?

(4) Does the microsite affect temperature-RW relationships?

(5) Does the microsite affect PDSI-RW relationships?

(6) Does the microsite affect temperature-LBI relationships?

(7) Does the microsite affect PDSI-LBI relationships?

Climate variables used in the LMMs were selected based on the results of climate-growth analyses (see section "Results").

First, the questions 1, 2, and 3 can already be explored visually by comparing the two microsites' regional curves (Bowman et al., 2013), which describe the expected RW, BAI, or LBI at each age (Supplementary Figure S6). Therefore, in the respective models we used the expected RW/BAI/LBI according to the sites' (not microsite) regional curves as an input parameter to account for tree age/size effects. The regional curves were calculated with the $r c s$ function ( $d p l R$ package in R; Bunn, 2008). Previous year's growth value was used as an input parameter to account for autocorrelation. This previous year's value was standardized (mean $=0, \mathrm{SD}=1$ ) for each tree to avoid multi-collinearity with the microsite effect. Microsite was used as a fixed effect, tree-ID was used as a random intercept, while previous year's growth 
value in dependence in tree-ID was used as random slope. To compare the models with and without the microsite effect, we fitted these models with the maximum likelihood method (ML), because both models differed only in fixed (microsite) effects.

For the models that explored the effect of microsite on climate-growth responses (questions: 4, 5, 6, and 7), we used 30year spline detrended data instead of raw tree-ring data (RWI and LBII instead of RW and LBI). This detrending generally removes all low frequency variability and benefits the detection of high frequency climatic signals in tree-ring chronologies. The respective independent variables in these models are: previous year's growth index in order to account for autocorrelation and the site- or sub-region- specific climate variable. To test the microsite effect, we compared this model to a model that additionally included the microsite as well as the interaction of microsite and climate variable. Again, models with and without the microsite effect were fitted via the maximum likelihood method (ML), because both models only differed in their fixed effects. All formulas of the tested models are listed in Supplementary Table S2. All analyses were computed in " $R$ " (version 3.6.3.; R core team, 2018).

\section{RESULTS}

\section{Similarities of Growth Patterns Across the Tree-Ring Network}

The mean age of the trees per microsite ranged from 117 to 228 years (overall mean 157 years) with older trees growing in the northern (mean age 186 years) than in the southern (mean age 139 years) sub-region. Six sites showed significant difference in tree age; at three sites trees were older on the dune ridge while at the other three sites, trees were younger on the dune ridge. Within six sites tree heights were significantly different, with taller trees at the bottom (four sites) compared to the dune ridge (two sites; Table 2). We found a significant difference in $\mathrm{DBH}$ between microsites (ridge vs. bottom) only at two sites, where trees growing on the dune ridge had larger $\mathrm{DBH}$ measurements. Overall, mean RWs and BAI were greater in the southern (Germany and Poland) than in the northern (Estonia and Sweden) pine populations (Table 2). We documented a significant difference in mean RW at all sites; at five sites mean RW was greater at the bottom of the dune compared to the dune ridge (four sites). Five sites showed significant difference in mean BAI; at three sites BAI was greater at the bottom of the dune while at the other two sites BAI was greater at the dune ridge (Table 2). At eight sites we observed significant differences in thickness of organic layer, where humus depth was greater at the bottom (seven sites) of the dune than at the ridge (one site; Table 2). We identified a strong common signal in detrended tree-ring series (Supplementary Figure S1), with high values of EPS, GLK, and moderate values of Rbar (Supplementary Table S1).

Hierarchical cluster analysis conducted on the residual RW and LBI chronologies clustered microsite chronologies into two groups that represent two geographical sub-regions: north and south (Figure 2). We identified significant cross-correlations among microsite chronologies within each sub-region (RW north: $r=0.19$ to $r=0.68, p<0.05$ and $p<0.001$, respectively; RW south: $r=0.19$ to $r=0.84, p<0.05$ and $p<0.001$, respectively; LBI north: $r=0.2$ to $r=0.77, p<0.05$ and $p<0.001$, respectively; LBI south: $r=0.22$ to $r=0.82, p<0.05$ and $p<0.001$, respectively; Supplementary Figure S2). We found highly significant intra-site (ridge-bottom chronologies) correlations, ranging from RW: $r=0.67$ to $r=0.68(p<0.001)$ and LBI: $r=0.5$ to $r=0.79(p<0.001)$ in the northern and from RW: $r=0.52$ to $r=0.83(p<0.001)$ and LBI: $r=0.58$ to $r=0.75(p<0.001)$ in the southern sub-regions (Supplementary Figure S2). Interestingly, we also observed highly significant correlations between RW and LBI chronologies within both subregions (Supplementary Figure S3).

Considering the results from the HCA and high crosscorrelations among the RW and LBI microsites' chronologies in each sub-region (Figure 2 and Supplementary Figure S2), we decided to combine microsite chronologies into four subregional chronologies. Consequently, we obtained two northern
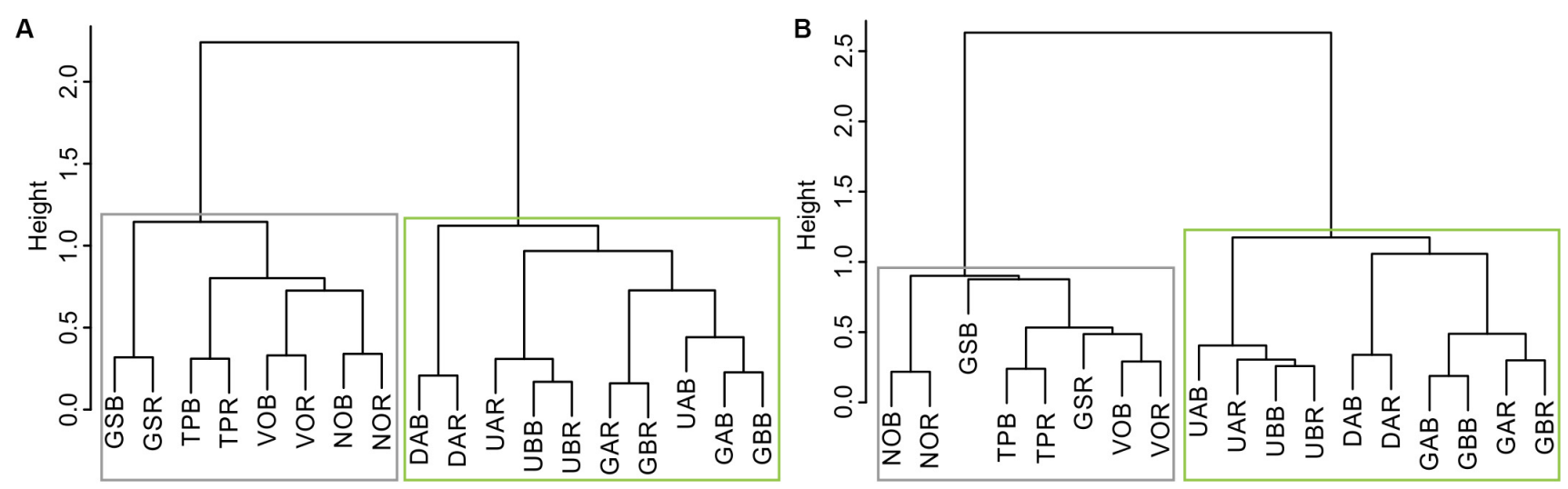

FIGURE 2 | Dendrogram of hierarchical cluster analysis based on microsites: (A) ring-width and (B) latewood blue intensity chronologies over the 1903-2016 period. Boxes represent two sub-regions (gray = north and green = south) in which our microsites were partitioned. The abbreviations of microsite names are explained in Table $\mathbf{1 .}$ 
(RW-N and LBI-N, both including: GS, TP, NO, VO; see Figure 2) and two southern (RW-S and LBI-S, both including: DA, UA, UB, GA, GB; see Figure 2) sub-regional chronologies for climate-growth analyses.

\section{Dominant Climate Signals}

At the regional scale, both proxies, RW and LBI show similar strength and direction of climate-growth responses over the 1903-2016 period, with a significant and positive influence of winter-spring temperature on tree growth (Figure 3; for temperature-growth responses of specific microsite chronologies see Supplementary Figure S4). At the site level, we identified a positive relationship of both RW and LBI to winter-spring/summer moisture availability (expressed as PDSI, Supplementary Figure S4) which, however, was not strongly represented in the sub-regional chronologies (Figure 3).

The RW-N and RW-S chronologies are positively correlated with winter-spring temperature $(0.3<r<0.5)$, with stronger associations found for the southern pine populations (Figure 3A). In contrast to climate-RW relationships, the association between LBI-N chronology to winter-spring temperature is stronger than for the LBI-S chronology $(0.3<r<0.5$ and $0.2<r<0.4$, respectively; Figure 3B). In the microsite analysis, we detected very few significant positive and negative relationships between precipitation sums and Scots pine growth (Supplementary Figure S4).

\section{Temporal Variability of Climate Signal}

Overall, we observed changes in Scots pine climate-growth responses over the two intervals examined (1903-1959 and 1960-2016; Figure 4, Supplementary Figure S5). In general, the winter-spring temperature-growth relationship is decreasing in the latter 20th and early 21st centuries, with the exception of the sites in the LBI-S network, which show a stronger relation to winter-spring temperature in the second interval. The direction of the temperature-RW and LBI response, however, does not change, and it remains positive and spatially significant across the study region (Figure 4, for temperature-growth responses of specific microsite chronologies and two intervals see Supplementary Figure S5). The relationships between microsite RW, LBI chronologies, and moisture availability (PDSI) calculated over the full overlap are positive and comparably strong to temperature, which, however, is not resembled by the sub-regional chronologies (Figure 4, for drought-growth responses of specific microsite chronologies and two intervals see Supplementary Figure S5).

\section{Microsite Effect on Growth and Climate-Growth Relationships}

In general, the LMMs indicate that microsites often have an effect according to the deltaAIC, but the change in the marginal $R^{2}$ in the majority of cases is $<0.01$. In the analyses of the northern and southern sub-regions, the largest effect of microsites was found for LBI in the southern sub-region (delta AIC $=-8.699$ ), however, in this case the marginal $R^{2}$ improved by only 0.017 . The LMMs thus revealed only minor effects of microsite conditions on absolute growth in the northern and southern sub-regions. At the individual site level, we found that microsite had marginal effects on RW and BAI (maximum delta AIC and delta marginal $R^{2}$ values were -11.592 and 0.027 for site GA Supplementary Table S2), while microsite affected LBI significantly at multiple sites. The strongest effects were noted for the sites VO, UA, UB, with delta AIC values of $-82.811,-15.269$, and -11.149 , and delta marginal $R^{2}$ values of $0.325,0.098$, and 0.079 (Supplementary Table S2).

The effect of microsite conditions on climate-growth relationships was not significant or very small for the northern
A
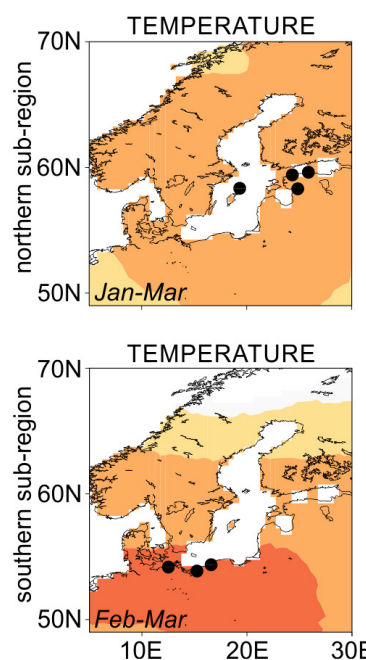
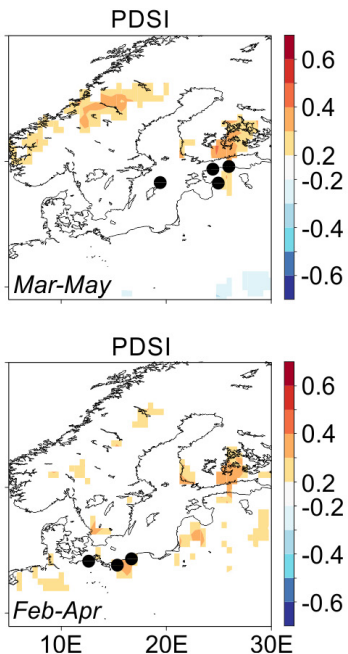

B
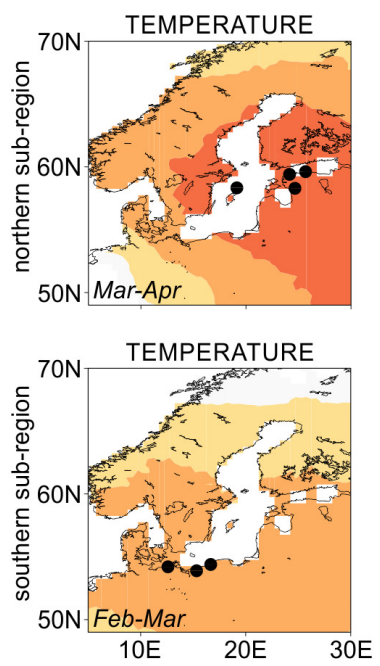
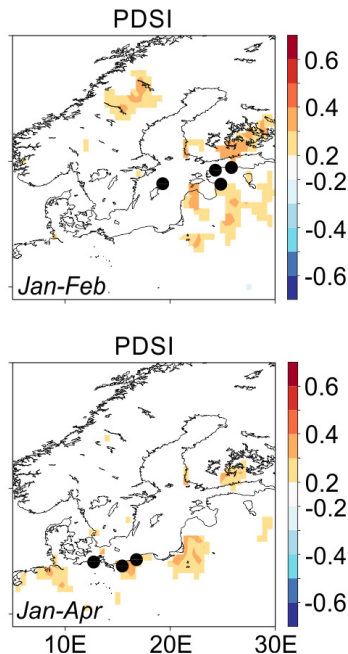

FIGURE 3 | Spatial Pearson's correlation maps for northern and southern sub-regions' chronologies for (A) ring-width and (B) latewood blue intensity against winter-spring temperature and drought variables (see inset text in each panel for climate season). Dots representing sites GA and GB as well as UA and UB overlap each other due to the small distance between sites (see the detailed location of each site on Figure 1). Correlations are based on the 1903-2016 common period. Dots correspond to tree-ring sites presented on the Figure $\mathbf{1}$ and in Table 1. White color within lands' borders represents non-significant values of correlations. 

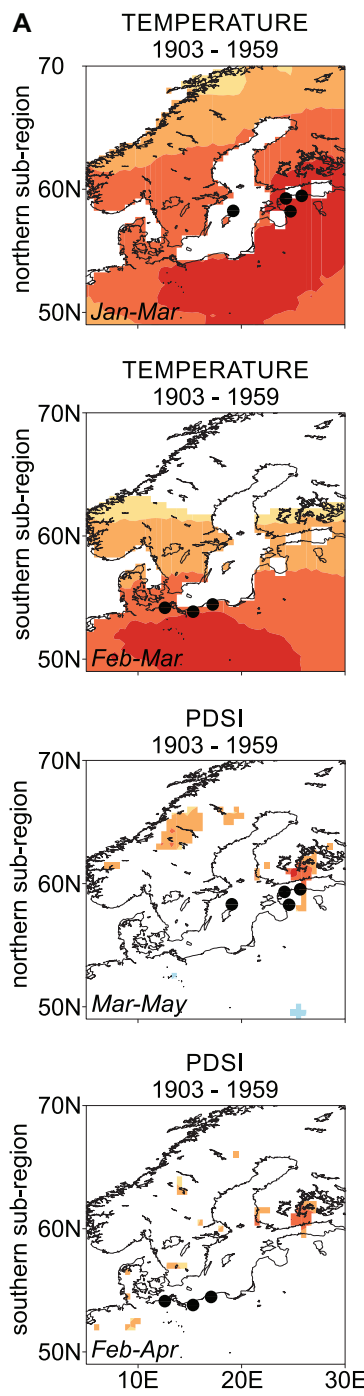

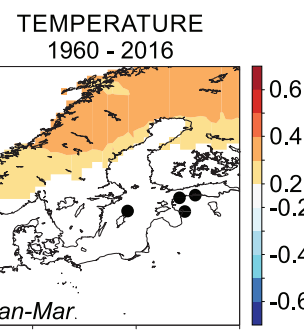

TEMPERATURE 1960 - 2016

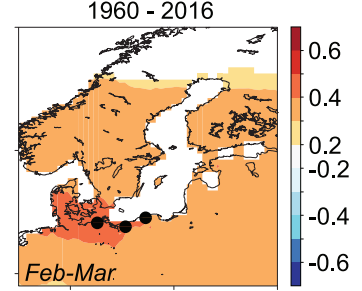

PDSI

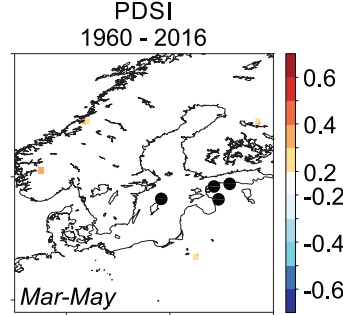

Mar-May

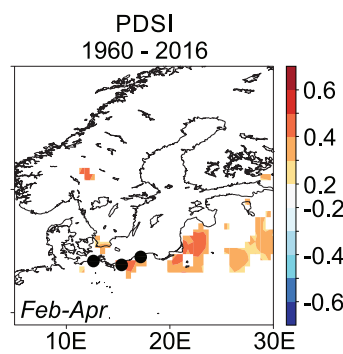

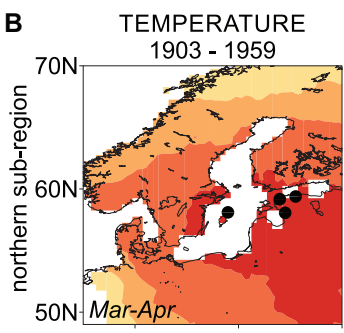

TEMPERATURE

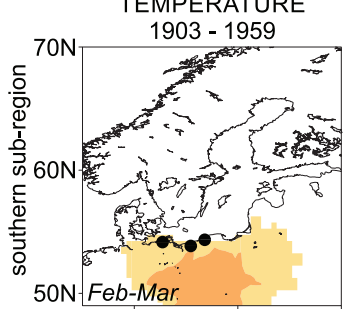

PDSI

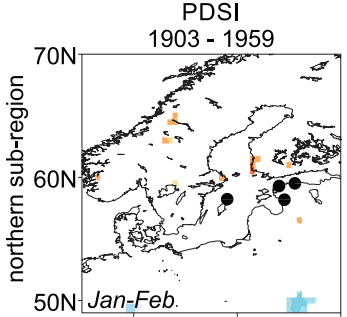

$50 \mathrm{~N}-\mathrm{Jan}-\mathrm{Feb}$

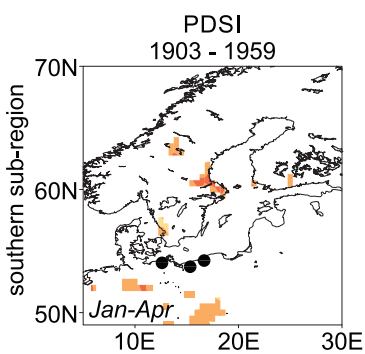

TEMPERATURE

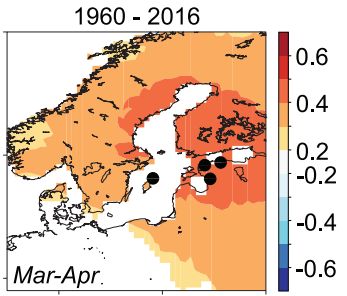

TEMPERATURE 1960 - 2016

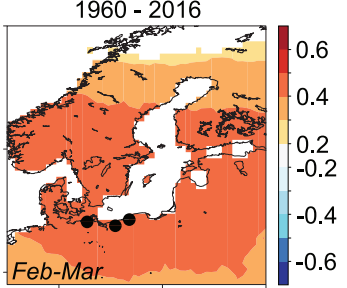

PDSI

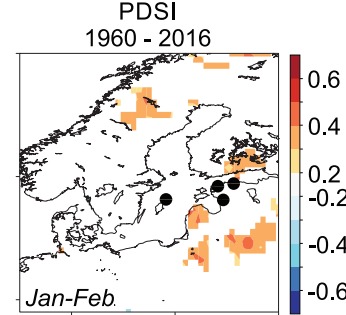

PDSI

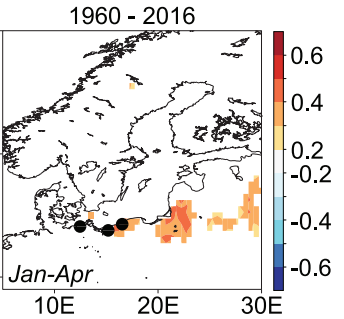

FIGURE 4 | Spatial Pearson correlation maps for northern and southern sub-regions chronologies assessing relationships between (A) ring-width, (B) blue intensity and winter-spring temperature and drought variables (see inset text in each panel for climate season). Dots representing sites GA and GB as well as UA and UB overlap each other due to the small distance between sites (see the detailed location of each site on Figure 1). Correlations are based on the 1903-1959 and 1960-2016 intervals. Dots correspond to tree-ring sites shown on Figure 1 and in Table 1. White color within lands' borders represent non-significant correlations.

and the southern sub-regions, as well as for individual sites. However, for multiple sites delta AIC was significantly negative, indicating microsite conditions play a role in the climate sensitivity of Scots pine growth, however, the delta marginal $R^{2}$ was never above 0.015 , indicating only small effects (Supplementary Table S2). For certain studies including climate reconstructions such differences might matter.

\section{DISCUSSION}

Tree growth in temperate forests is affected by multiple factors acting on different spatial and temporal scales. Climate drives tree growth at the regional scale, and this regional climategrowth response pattern is further modulated at the local scale by (micro)site conditions and microclimate (e.g., local summer precipitation; Briffa et al., 2002a,b). Our results show that regional climate primarily drives the growth and climategrowth responses of Scots pine on the coastal sand dunes around the south Baltic Sea. However, this growth and climate-growth responses are slightly modulated by (micro)site conditions.

\section{Scots Pine Growth and Dominant Climate Signal}

Considering the differences in microsite (dune ridge and bottom) conditions in our study that were reflected in differences in forest type and humus depth (Tables 1, 2), we expected to see microsite-specific patterns across all our sites: reduced growth (DBH, RW, BAI, tree height) of Scots pines on the dune ridges compared to the bottom of the dunes. Interestingly, although 
we identified some differences in Scots pine growth at the dune ridge and bottom, we did not observe homogenous growth tendencies related to these microsite settings, i.e., Scots pine growth (DBH, RW, BAI, tree height) was not always reduced on the dune ridge compared to the dune bottom as expected (Table 2 and Supplementary Figure S6; Örd, 1972; Pärn, 2002, 2008; Mandre et al., 2010). We also anticipated variability among trees growing at different microsites in terms of RW and LBI responses to climate (Supplementary Figure S4; RW: coastal sand dunes: Pärn, 2002; Mandre et al., 2010; sites with different soil compositions: Hordo et al., 2009; Cedro and Lamentowicz, 2011; Dauškane and Elferts, 2011; Edvardsson et al., 2015; Metslaid et al., 2018). Further, we anticipated a comparatively lower influence of temperature and substantial, positive and increased role of moisture availability on Scots pine growth on the dune ridge for the whole 1903-2016 period (Mandre et al., 2010). In our tree-ring network, regardless of the coastal character of our sites, location on the sand dunes, and the microsite type, we identified winter-spring temperature as a factor driving Scots pine RW and LBI at the regional and local scales. We additionally documented a strong and positive role of winterspring/summer moisture availability (expressed by PDSI) on Scots pine RW and LBI, which was not represented by the subregional chronologies. It is important to note that apart from the generally similar pattern of climate-growth responses across our network, we did observe subtle differences in the strength of temperature- and/or drought-growth responses between dune ridge and bottom microsites (Supplementary Figure S4). We observed very weak precipitation-growth relationships at only a few sites that were statistically significant for single months (Supplementary Figure S4).

Our findings on the influence of warmer winter-spring conditions on Scots pine RW (Figure 3 and Supplementary Figure S4) is consistent with previous studies conducted in this region that also report winter-spring temperature as a factor promoting Scots pine growth (Cedro, 2001; Vitas, 2004; Elferts, 2007; Vitas and Erlickytè, 2007; Hordo et al., 2009; Pärn, 2009; Cedro and Lamentowicz, 2011; Metslaid et al., 2018; Harvey et al., 2020). Different climate-growth responses, i.e., positive response to previous and current year winter and summer temperature and precipitation, negative influence of winterspring precipitation (Vitas and Bitvinskas, 1998; Cedro and Lamentowicz, 2011; Hordo et al., 2011) for Scots pine in the region have also been reported. Interestingly, studies conducted on the coastal dune sites in Estonia (Pärn, 2002; Mandre et al., 2010) found elevation differences play a strong role on Scots pine climate-growth relationships. Pärn (2002) reported a combined effect of temperature and precipitation on Scots pine growth, however, with some variability in climate response driven by tree age and the position on the dune. The author documented significant influence of winter temperature on Scots pine growth at more than half of the sample plots located within western and eastern slopes of the dune. Additionally, at some of these sample plots, the influence of precipitation was detected, however, the overall correlation values were lower than for temperature. Mandre et al. (2010) documented only a significant influence of winter precipitation/snowfall on pines' growth (i.e., no significant temperature response), where trees growing on the dune ridge exhibited a positive relationship to winter precipitation and trees at the dune bottom grew poorly with increased winter precipitation. The general differences documented by Pärn (2002), Mandre et al. (2010), and in our study might result from different age of the trees used in the analyses (Pärn, 2002 and Mandre et al.: $\sim 50$ and 100-200 years old; our study: $\sim 100-400$ years old), as well as the time interval for which the analyses were performed (Pärn, 2002: 1952-2000, Mandre et al., 2010: 1963-2002, our study: 1903-2016). Moreover, we raise a statistical issue and suggest that the use of different $p$-values (Mandre et al., 2010 and Pärn, 2002: $p<0.05$ : our study: $p<0.01$ ) to quantify the statistical significance of the results would have brought distinct differences in the results (Vidgen and Yasseri, 2016). As we reported a few significant relationships between precipitation sums and growth (Supplementary Figure S4), we admit that the use of higher $p$-value $(p<0.05)$ in our analysis, would have resulted in more significant correlation scores (tested, not presented). It is important to note that precipitation has an impact on Scots pine growth at some of our sites (Supplementary Figure S4), however, considering our aim to detect the dominant drivers of growth and following the recommendation of Vidgen and Yasseri (2016), we rely on the lower $p$-value in order to improve the quality of statistical significance. Thus, we indicate that the role of precipitation is negligible to moderate as a climate factor influencing the growth of Scots pine.

The positive relationship between Scots pine growth and warmer winter-spring conditions seems to highlight the species capacity to capitalize on positive early growing season conditions. Warm thermal conditions in the winter-spring season can trigger earlier cambial activity and in turn an earlier onset of growth leading to a wider tree ring (Cedro and Lamentowicz, 2011). Further, higher temperatures in the cold season may result in less cambium, needle, and root damage and therefore ease winter growth limitations and earlier growth resumption (Havranek and Tranquillini, 1995; Dauškane et al., 2011). Sevanto et al. (2006) documented that Scots pine photosynthesis and diurnal stem diameter variations begin and end when air temperature reaches $3-4^{\circ} \mathrm{C}$ and drops below $-7^{\circ} \mathrm{C}$, respectively, as long as enough water is available for wintertime photosynthesis. On the other hand, low temperatures and a deep snow cover may significantly reduce radial growth by keeping soil temperature low and delaying the initiation of cambial activity in spring (Peterson and Peterson, 2001; Dauškane et al., 2011). Increasing and fluctuating winter-spring temperature might also have a negative influence on tree growth, i.e., decreased tree resistance to low temperatures (Koprowski, 2013). Lastly, warmer conditions can interrupt the hardening processes of trees and increase their sensitivity to late winter-early spring frost (Koprowski, 2013; Misi and Nafradi, 2016).

The identified local and positive relationship between Scots pine growth and winter-spring/summer moisture availability conditions in most microsites highlights Scots pine's requirement for moisture in the soil before and/or during the growing season, and further denotes dry conditions that specifically occur at certain site-types, i.e., at the coastal sand dunes/sandy 
soil (Pärn, 2002; Vitas, 2006; Mandre et al., 2010) but also rocky shallow soils (Lindholm et al., 1997; Seftigen et al., 2013, 2020). This is not unexpected since coastal dune sites consist of sandy soils with poor water holding capacities (Mandre et al., 2010). Therefore, higher winter-spring temperatures on the one hand might cause less limitation for growth, while at the same time due to hydrological properties of soil/sand intensified by the drying effect of the sun and wind, drought events may occur, especially at the dune ridge, and lead to secondary stress resulting in decreased ion uptake and changes in metabolic activity (Mandre et al., 2010). Further, due to elevated soil aeration on sandy soils, transpiration may increase and finally lead to water stress (Rigling et al., 2001). The inconsistent and weak spatial climate correlations of sub-regional chronologies with PDSI (Figures 3, 4) can be explained with the comparably lower spatial autocorrelation of PDSI compared to temperature. That is, each of the nine investigated sites receive considerably different precipitation amounts in a given year which are restricted to the local events (HELCOM, 2013), while the high spatial autocorrelation of temperature results in a more or less similar thermal regime across the network. Consequently, the temperature signal is well represented in the spatial climate correlations compared to the rather local precipitation (PDSI) signals.

In contrast to the strong relationships between drought (PDSI) and Scots pine growth at some sites, the weak or lack of moisturegrowth responses at other sites (at both, dune ridge and bottom microsites; Supplementary Figure S4) might be associated with several factors. First, locally occurring precipitation could provide enough soil moisture to prevent trees from droughtstress (Pärn, 2002; Mazza and Manetti, 2013). Second, abundant snowpack in winter may constitute a source of soil moisture in spring when soil water shortage diminishes nutrient and water availability to tree roots (Mandre et al., 2010). Third, sandy soil features low water-holding capacity and high permeability (Mandre et al., 2010). In turn, the irrigation effect of precipitation events is rather minor, and the moisture conditions do not differ much within the year or between years. It might suggest that drought stress on such soils stays at roughly the same level, and thus Scots pine growth is more balanced (Rigling et al., 2001). Additionally, the number of precipitation events is suggested (Rigling et al., 2001) to be more influential on tree growth rather than the amount of rain. Fourth, the multi-layered root system could permit Scots pine to obtain water from deeper levels of the soil profile especially at the sites with undulating terrain or small dunes providing sustained water resources to coastal trees (Frattegiani et al., 1994). Fifth, the negligible or lack of influence of moisture availability on Scots pine growth might be associated with anthropogenic influence related to, among others, waterlogging that we describe in more detail later in the discussion.

To the best of our knowledge, there is just one study (Seftigen et al., 2020) that tested the influence of climate on BI in Scots pine in this part of the Baltic Sea, however, site conditions in Seftigen et al. (2020) and our study significantly differed (rocky shallow soils vs. coastal sand dunes). We found that LBI was positively related to winter-spring temperature and winter-spring/summer moisture availability (Figure 3 and Supplementary Figure S4), while Seftigen et al. (2020) demonstrated an association of EBI to late winter through early summer temperature. The authors hypothesized that this relationship could be associated with earlier cambial activation and prolonged duration and rate of metabolic processes that enhance carbohydrate synthesis, lignification and cell wall synthesis of earlywood tracheids as a reaction to warmth early in the growing season. Additionally, we hypothesize that higher winter-spring temperature allows trees to accumulate more nonstructural carbohydrates, which can be used by a tree for cell wall reinforcement later in the year. Moreover, warmer winter-spring season could also indicate an earlier onset of the growing season and thus a longer vegetation period. More growth early in the growing season could potentially result in earlier cell division and enlargement permitting more time for cell wall thickening. Other assessments of climate influence on a measure of Scots pine LBI in Europe come from central (Björklund et al., 2015; Fuentes et al., 2018) and northern Scandinavia (Campbell et al., 2007; Björklund et al., 2013) as well as Scotland (Rydval et al., 2014; Wilson et al., 2016) and collectively report a positive correlation of LBI to summer temperature. Sites sampled in these studies are located at higher latitudes and/or in subalpine environments where tree growth is often limited by low summer temperatures and a short growing season leading to high temperature sensitivity.

Contrary to our expectations, we found only marginal effect of microsite on absolute Scots pine growth as well as on climategrowth relationships. The LMMs distinguished variability in growth patterns and climate-growth relationships of Scots pine between microsites at the same site only in some cases (Supplementary Table S2). To interpret this result we consider three possible explanations: (1) The relative height difference between some microsites was too small to see pronounced differences in tree growth and local climate responses. (2) Previous research has demonstrated higher climate sensitivity of taller and older trees, especially with moisture-related parameters or temperature-induced stress (Ryan et al., 2006; Trouillier et al., 2019). Contrarily, higher climate sensitivity has also been reported for smaller and younger trees, which might be related to prolonged vegetation season and lower rooting depth documented for small trees (Zeng et al., 2018; Trouillier et al., 2019). Due to the generally similar age structure and tree height at the dune ridge and bottom (although statistically significant differences are present), the age- and/or size-related effects on climate responses seem to be relatively small across our treering network. (3) With respect to climate-growth responses, monthly climate variables explain relatively little variance relative to autocorrelation, age/size effects, and the cumulative effect of all other monthly climate variables combined. Thus detecting changes in an already small effect is challenging and might require larger sample sizes.

Despite the marginal microsite effect identified by the LMMs, it is important to note that we observed differences of absolute BAI and LBI between microsites at several sites (Supplementary Figure S6). More specifically, throughout several decades up to the whole observational period some sites (e.g., GS for RW and BAI, TP for LBI; Supplementary Figure S6) featured higher 
$\mathrm{BAI} / \mathrm{LBI}$ at the dune ridge in contrast to the other sites (e.g., GB for BAI and VO for LBI; Supplementary Figure S6) presenting higher BAI/LBI at the bottom of the dune.

General differences observed in BAI values might result, not only from the ecological and geomorphological features of the coastal sand dunes, but also site-specific history. For example, considerably different BAI values recorded for the Swedish microsites: GSR and GSB are most likely associated with different tree age (Table 2). Differences in tree age may be driven by different disturbance histories such as humaninduced and natural fires as well as tree logging, sanitary cuttings, and thinning that took place on the Gotska Sandön island over the past five centuries (Niklasson, 2015). We mainly observed evidence of logging at the bottom of the dune which resulted from much easier access to the trees compared to the trees growing on the $40 \mathrm{~m}$ dune. Further, possible differences in Scots pine growth within Polish sites (UA, UB, GA, GB) might also result from the anthropogenic influence, i.e., forest management (tree logging and planting), as well as intensive tourism development. The latter is associated with, among others, trampling that was confirmed to significantly affect Scots pine growth in NE Poland (Matulewski et al., 2019). Lack of significant differences in Scots pine growth at the German DAR and DAB microsites might be associated with the fact that the area was extensively deforested in the 18th century. Moreover, large tree size (expressed by large values of BAI, mean RW; Table 2) at both microsites might be associated with the construction of drainage ditches at the beginning of the 19th century that led to long-lasting water logging and further changes in the landscape, which was redesigned for industrial cattle production in the second half of the 20th century. Later, large cattle areas got drained leading to soil and water contamination (fertilization; Bauer and Scheytt, 2019). Although past human-induced activates, natural and near-natural landscapes have been preserved and led to the establishment of numerous nature reserves and the designation of the Vorpommersche Boddenlandschaft national park at the end of the 20th century. Little is known about the history of the sites located in Estonia (VO, TP, NO). However, it is confirmed that the forests have been managed in terms of selective or sanitary cuttings (dead, dying, or infected trees were removed).

We suggest, that the factors driving Scots pine growth leading to certain differences and similarities should be summarized as an interaction between climate, elements of sand dune ecology (i.e., biological and physico-chemical features) and landuse history. Although we provided some possible explanations for documented differences and similarities in Scots pine growth across our sites, we postulate that this inconsistency of observations indicates the necessity for further investigations into the underlying drivers of Scots pine growth (represented by BAI) and LBI.

\section{Temporal Variability of Climate-Growth Responses}

When we compared climate-growth responses over the two studied intervals (1903-1959, 1960-2016) we found differences in the strength of the relationships (Figure 4 and Supplementary
Figure S5). Similar to Pärn (2009) and Metslaid et al. (2018), we observed a decreasing relationship between winterspring temperatures and RW chronologies over the studied intervals (Figure 4A and Supplementary Figure S5) suggesting that higher winter-spring temperatures did not necessarily stimulate Scots pine growth at least in the second studied interval. In contrast, Harvey et al. (2020) used a network of more than 100 Scots pine RW chronologies from the south Baltic Sea region and reported a generally synchronous and stable response to late winter/early spring (February and March) temperatures, and increasing, positive relationship to January temperature suggesting that warmer winter temperature promotes Scots pine growth.

Further, we documented an increased role of moisture availability on Scots pine growth in the second interval (19602016) which was particularly important for most of the sites (dune ridge and bottom) located in the southern sub-region (Supplementary Figure S4). Our findings might indicate that in general warmer and drier winter-spring/summer seasons (von Storch et al., 2015) cause more drought stress for trees at the coastal sand dune sites, however, this drought stress is not equal across the tree-ring network due to a multitude location-specific site-, tree-, and drought related factors as well as their interactions (Bose et al., 2020).

Instabilities in climate-growth responses and the general discrepancies in the temporal stationarity of climate-growth responses documented in our study and the studies mentioned above, suggest the importance of several co-occurring factors acting at different temporal and spatial scales. Climate changes are not uniform at a broader geographical scale (von Storch et al., 2015), which means that the documented increasing trend in winter-spring temperature is not necessarily homogenous across the whole Baltic Sea area. Moreover, specific local site conditions together with variations in local climate (e.g., coastal site characteristics, local precipitation), and varying stand age could contribute to the discrepancies in temporal stationarity of climate-growth responses documented in our and other studies. Further, the use of a greater number of intervals, different interval's length or alternative periods could also influence results (Allen et al., 2018) reported by Harvey et al. (2020) (31 years moving windows lagged by 1 year over the 19432002 interval) and in our study (two-interval approach over the 1903-1959 and 1960-2016 intervals). Undoubtedly, each of the methods used to detect temporal instabilities has its limitation, thus should be chosen carefully depending on the aim of the study (Allen et al., 2018). Finally, in the first half of the 20th century the lower number of station climate data contributing to the gridded climate data could cause artificial climate-growth instabilities because the interpolation was based on less station data and therefore interpolated from farther away compared to the second half of the 20th century (Allen et al., 2018). However, Pärn (2009) and Metslaid et al. (2018) documented non-stationary climate-growth relationships over the 1950 to 2000 and 1955 to 2006, respectively, and relied on station climate data in their analyses.

The stationarity of climate-growth relationships for LBI differs between the northern and southern sub-region (Figure 4B and 
Supplementary Figure S5). In the north of the study region, we observed a decreasing role of winter-spring temperature on growth (LBI), while in the south a slight increase was found. Similar to RW in the more recent interval we observed an increased and positive importance of moisture availability on LBI across the southern sites and decreased role in the northern sub-regions. Seftigen et al. (2020) also documented a weakening relationship between the late winter through early summer temperature and EBI. To the best of our knowledge, there are no other previous studies that test the stationarity of the climate signal derived from LBI in the south Baltic Sea area or in Scandinavia. Although it is difficult to explicitly explain the relationship between the winter-spring temperature, winter-spring/summer moisture availability and LBI, we believe that the non-stationarity of these climate signals is most likely associated with 20th century climate warming.

\section{SUMMARY AND OUTLOOK}

In this network study we found that the growth of Scots pine trees is positively influenced by winter-spring temperature at a broad-scale and further modulated by winter-spring/summer moisture availability at local scales. Furthermore, we documented that at the regional scale, coastal dune ridge and bottom microsite characteristics are of comparably lower importance for Scots pine growth and climate-growth responses than expected, however, at the local scale some sites featured non-systematic differences. Our findings contribute to the existing knowledge about variables stimulating Scots pine growth in the transition zone from boreal to temperate forests of Europe (Pärn, 2002; Vitas, 2006; Mandre et al., 2010; Cedro and Lamentowicz, 2011; Hordo et al., 2011; Metslaid et al., 2018; Matisons et al., 2019; Harvey et al., 2020). The localized character of the winter-spring/summer drought signal indicates that Scots pine-dominated dune forests are generally vulnerable to soil moisture availability (Vitas, 2004, 2006; Vitas and Erlickyte, 2007). The examination of LBI provides new insight into Scots pine growth responses to climate in this region. Similar to RWs, we identified the broad-scale, positive influence of winter-spring temperature and local-scale winter-spring/summer moisture availability. Generally, we found the strength and direction of climate signal was comparable for the RW and LBI chronologies, which was expected as we documented high cross-proxy correlations (Seftigen et al., 2020).

The documented temporal variability of growth responses to winter-spring temperature and winter-spring/summer moisture availability, particularly evident at local scales and reflected in a noticeable shift in a climate variable driving Scots pine growth (stronger influence of moisture availability in the second interval), could be a result of ongoing climate change. Overall, considering projected winter-spring temperature increase (3$4^{\circ} \mathrm{C}$ over the next 80 years; Neumann, 2010), changes in the precipitation regimes, and frequency and magnitude of droughts in the Baltic Sea region (von Storch et al., 2015), further research is required to better understand whether Scots pine will perform better or worse under future climate change. In the context of our findings, we postulate that the vulnerability of Scots pine growth on the coastal sand dunes around the south Baltic Sea will depend on the winter warming balance coupled with intensified water stress during periods of growing-season warming and diminished precipitation.

We hope that our study inspires further exploration on the effect of microsite conditions on Scots pine RW, LBI, and climate-growth relationships with a special emphasis on temporal changes in climate-growth responses and mechanisms explaining the non-systematic differences in growth and LBI between dune ridge and bottom. Additionally, we recommend a detailed investigation of cambial activity and xylem formation that could help to answer the question why Scots pine growth is strongly controlled by winter-spring temperature in a boreal-temperate transition zone.

\section{DATA AVAILABILITY STATEMENT}

The raw data supporting the conclusions of this article will be made available by the authors, without undue reservation.

\section{AUTHOR CONTRIBUTIONS}

KJ and MW designed the study. KJ, MW, RK, SM, MM, and $\mathrm{AB}$ collected the data. $\mathrm{KJ}$ analyzed the data with input from MW, MT, AB, and JH. KJ wrote the first draft of the manuscript with contributions from $\mathrm{MW}$ and $\mathrm{JH}$. All authors contributed to manuscript revision, read, and approved the submitted manuscript.

\section{FUNDING}

KJ was supported by the Deutscher Akademischer Austauschdienst (DAAD). This research was funded by research consortium BaltRap (The Baltic Sea and its Southern Lowlands: Proxy-Environment interactions in times of rapid changes) funded by the Leibniz Association and the Estonian University of Life Sciences (projects P180024MIME and P200029MIME).

\section{ACKNOWLEDGMENTS}

We thank Petter Rimfors, Örjan Siik, Magnus Lepschi, and Mats Niklasson for constructive advice during the fieldwork and Michał Lempa for assisting with Figure 1.

\section{SUPPLEMENTARY MATERIAL}

The Supplementary Material for this article can be found online at: https://www.frontiersin.org/articles/10.3389/ffgc.2020. 578912/full\#supplementary-material 


\section{REFERENCES}

Allen, K. J., Villalba, R., Lavergne, A., Palmer, J. G., Cook, E. C., Fenwick, P., et al. (2018). A comparison of some simple methods used to detect unstable temperature responses in tree-ring chronologies. Dendrochronologia 48, 52-73. doi: 10.1016/j.dendro.2018.02.002

Babst, F., Bodesheim, P., Charney, N., Friend, A. D., Girardin, M. P., Klesse, S., et al. (2018). When tree rings go global: challenges and opportunities for retroand prospective insight. Quatern. Sci. Rev. 197, 1-20. doi: 10.1016/j.quascirev. 2018.07.009

Babst, F., Bouriaud, O., Poulter, B., Trouet, V., Girardin, M. P., and Frank, D. C. (2019). Twentieth century redistribution in climatic drivers of global tree growth. Sci. Adv. 5:eaat4313. doi: 10.1126/sciadv.aat4313

Babst, F., Poulter, B., Trouet, V., Tan, K., Neuwirth, B., Wilson, R., et al. (2013). Siteand species-specific responses of forest growth to climate across the European continent. Glob. Ecol. Biogeogr. 22, 706-717. doi: 10.1111/geb.12023

Balanzategui, D., Knorr, A., Heussner, K. U., Wazny, T., Beck, W., Słowiński, M., et al. (2018). An 810-year history of cold season temperature variability for northern Poland. Boreas 47, 443-453. doi: 10.1111/bor.12274

Bates, D., Mächler, M., Bolker, B., and Walker, S. (2015). Fitting linear mixed-effects models using lme4. J. Stat. Softw. 67, 1-48. doi: 10.18637/jss.v067.i01

Bauer, F., and Scheytt, T. (2019). Hydrogeologie und Hydrologie der Halbinsel Darß-Zwischen Meerwasserintrusion und Landnutzung. Grundwasser 24, 197-208. doi: 10.1007/s00767-019-00426-x

Björklund, J., Gunnarson, B. E., Seftigen, K., Zhang, P., and Linderholm, H. W. (2015). Using adjusted blue intensity data to attain high-quality summer temperature information: a case study from Central Scandinavia. Holocene 25, 547-556. doi: 10.1177/0959683614562434

Björklund, J., von Arx, G., Nievergelt, D., Wilson, R., Van den Bulcke, J., Günther, B., et al. (2019). Scientific merits and analytical challenges of tree-ring densitometry. Rev. Geophys. 57, 1224-1264. doi: 10.1029/2019RG000642

Björklund, J. A., Gunnarson, B. E., Seftigen, K., and Esper, J. (2014). Blue intensity and density from northern Fennoscandian tree rings, exploring the potential to improve summer temperature reconstructions with earlywood information. Clim. Past 10:877. doi: 10.5194/cp-10-877-2014

Björklund, J. A., Gunnarson, B. E., Seftigen, K., Esper, J., and Linderholm, H. W. (2013). Is blue intensity ready to replace maximum latewood density as a strong temperature proxy? A tree-ring case study on Scots pine from northern Sweden. Clim. Past Discus. 9, 5227-5261. doi: 10.5194/cpd-9-5227-2013

Bogino, S., Fernandez Nieto, M. J., and Bravo, F. (2009). Climate effect on radial growth of Pinus sylvestris at its southern and western distribution limits. Silva Fennica 43, 609-623. doi: 10.14214/sf.183

Boisvenue, C., and Running, S. W. (2006). Impacts of climate change on natural forest productivity-evidence since the middle of the 20th century. Glob. Change Biol. 12, 862-882. doi: 10.1111/j.1365-2486.2006.01134.x

Bormann, H. (2010). Runoff regime changes in German rivers due to climate change. Erdkunde 64, 257-279. doi: 10.3112/erdkunde.2010.03.04

Bose, A. K., Gessler, A., Bolte, A., Bottero, A., Buras, A., Cailleret, M., et al. (2020). Growth and resilience responses of Scots pine to extreme droughts across Europe depend on pre-drought growth conditions. Glob. Change Biol. 26, 4521-4537. doi: 10.1111/gcb.15153

Bowman, D. M., Brienen, R. J., Gloor, E., Phillips, O. L., and Prior, L. D. (2013). Detecting trends in tree growth: not so simple. Trends Plant Sci. 18, 11-17. doi: $10.1016 /$ j.tplants.2012.08.005

Briffa, K. R., Osborn, T. J., Schweingruber, F. H., Jones, P. D., Shiyatov, S. G., and Vaganov, E. A. (2002a). Tree-ring-width and density data around the Northern Hemisphere: Part 1, local and regional climate signals. Holocene 12, 737-757. doi: 10.1191/0959683602hl587rp

Briffa, K. R., Osborn, T. J., Schweingruber, F. H., Jones, P. D., Shiyatov, S. G., and Vaganov, E. A. (2002b). Tree-ring-width and density data around the Northern Hemisphere: Part 2, spatio-temporal variability and associated climate patterns. Holocene 12, 759-789. doi: 10.1191/0959683602hl588rp

Brown, J. H., and Schwemler, S. A. (1990). Suitability of Scotch Pine varieties for windbreak and urban screen plantings. Res. Circ. 196, 1-9.

Bukantis, A., and Rimkus, E. (2005). Climate variability and change in Lithuania. Acta Zool. Lituanica 15, 100-104. doi: 10.1080/13921657.2005.10512382

Bunn, A. G. (2008). A dendrochronology program library in R (dplR). Dendrochronologia 26, 115-124. doi: 10.1016/j.dendro.2008.01.002
Buras, A. (2017). A comment on the expressed population signal. Dendrochronologia 44, 130-132. doi: 10.1016/j.dendro.2017.03.005

Buras, A., Schunk, C., Zeiträg, C., Herrmann, C., Kaiser, L., Lemme, H., et al. (2018a). Are Scots pine forest edges particularly prone to drought-induced mortality? Environ. Res. Lett. 13:025001. doi: 10.1088/1748-9326/aaa0b4

Buras, A., Spyt, B., Janecka, K., and Kaczka, R. (2018b). Divergent growth of Norway spruce on Babia Góra Mountain in the western Carpathians. Dendrochronologia 50, 33-43. doi: 10.1016/j.dendro.2018.04.005

Burnham, K. P., and Anderson, D. R. (2004). Multimodel inference: understanding AIC and BIC in model selection. Sociol. Methods Res. 33, 261-304. doi: 10.1177/ 0049124104268644

Campbell, R., McCarroll, D., Loader, N. J., Grudd, H., Robertson, I., and Jalkanen, R. (2007). Blue intensity in Pinus sylvestris tree-rings: developing a new palaeoclimate proxy. Holocene 17, 821-828. doi: 10.1177/0959683607080523

Campbell, R., McCarroll, D., Robertson, I., Loader, N. J., Grudd, H., and Gunnarson, B. (2011). Blue intensity in Pinus sylvestris tree rings: a manual for a new palaeoclimate proxy. Tree Ring Res. 67, 127-134. doi: 10.3959/2010-13.1

Cedro, A. (2001). Dependence of radial growth of Pinus sylvestris L. from Western Pomerania on the rainfall and temperature conditions. Geochronometria 20, 69-74.

Cedro, A., and Lamentowicz, M. (2011). Contrasting responses to environmental changes by pine (Pinus sylvestris L.) growing on peat and mineral soil: an example from a Polish Baltic bog. Dendrochronologia 29, 211-217. doi: 10.1016/ j.dendro.2010.12.004

Cook, E. R., Briffa, K., Shiyatov, S., and Mazepa, V. (1990). "Treering standardization and growth-trend estimation," in Methods of Dendrochronology: Applications in the Environmental Sciences, eds L. A. Kairiukstis, and E. R. Cook (Cham: Springer), 104-123.

Cook, E. R., and Peters, K. (1981). The smoothing spline: a new approach to standardizing forest interior tree-ring-width series for dendroclimatic studies. Tree Ring Bull. 41, 45-53.

Dauškane, I., Brūmelis, G., and Elferts, D. (2011). Effect of climate on extreme radial growth of Scots pine growing on bogs in Latvia. Estonian J. Ecol. 60, 236-248. doi: 10.3176/eco.2011.3.06

Dauškane, I., and Elferts, D. (2011). Influence of climate on Scots pine growth on dry and wet soils near Lake Engure in Latvia. Estonian J. Ecol. 60, 225-235. doi: 10.3176/eco.2011.3.05

Draveniece, A. (2009). Detecting changes in winter seasons in Latvia: the role of arctic air masses. Boreal Environ. Res. 14, 89-99.

Drobyshev, I., Niklasson, M., Linderholm, H. W., Seftigen, K., Hickler, T., and Eggertsson, O. (2011). Reconstruction of a regional drought index in southern Sweden since AD 1750. Holocene 21, 667-679. doi: 10.1177/0959683610391312

Düthorn, E., Holzkämper, S., Timonen, M., and Esper, J. (2013). Influence of micro-site conditions on tree-ring climate signals and trends in central and northern Sweden. Trees 27, 1395-1404. doi: 10.1007/s00468-0130887-8

Düthorn, E., Schneider, L., Günther, B., Gläser, S., and Esper, J. (2016). Ecological and climatological signals in ring-width and density chronologies along a latitudinal boreal transect. Scand. J. For. Res. 31, 750-757. doi: 10.1080/ 02827581.2016 .1181201

Düthorn, E., Schneider, L., Konter, O., Schön, P., Timonen, M., and Esper, J. (2015). On the hidden significance of differing micro-sites on tree-ring based climate reconstructions. Silva Fennica 49:1220. doi: 10.14214/sf.1220

Edvardsson, J., Rimkus, E., Corona, C., Šimanauskienè, R., Kažys, J., and Stoffel, M. (2015). Exploring the impact of regional climate and local hydrology on Pinus sylvestris L. growth variability-A comparison between pine populations growing on peat soils and mineral soils in Lithuania. Plant Soil 392, 345-356. doi: 10.1007/s11104-015-2466-9

Elferts, D. (2007). Scots pine pointer-years in northwestern Latvia and their relationship with climatic factors. Acta Univ. Latv. 723, 163-170.

Erlickyte, R., and Vitas, A. (2008). Influence of droughts to the radial growth of Scots Pine (Pinus sylvestris L.). Ekológia 27, 367-378.

Frattegiani, M., Mencuccini, M., Mercurio, R., and Profili, W. (1994). Quantitative analysis of Stone pine (Pinus pinea L.) root systems morphology and its relationships with water table and soil characters. Investig. Agraria Fuera de Ser $3,405-416$.

Fuentes, M., Salo, R., Björklund, J., Seftigen, K., Zhang, P., Gunnarson, B., et al. (2018). A 970-year-long summer temperature reconstruction from Rogen, 
west-central Sweden, based on blue intensity from tree rings. Holocene 28, 254-266. doi: 10.1177/0959683617721322

Gouirand, I., Linderholm, H. W., Moberg, A., and Wohlfarth, B. (2008). On the spatiotemporal characteristics of Fennoscandian tree-ring based summer temperature reconstructions. Theor. Appl. Climatol. 91, 1-25. doi: 10.1007/ s00704-007-0311-7

Gunnarson, B. E., Linderholm, H. W., and Moberg, A. (2011). Improving a treering reconstruction from west-central Scandinavia: 900 years of warm-season temperatures. Clim. Dyn. 36, 97-108. doi: 10.1007/s00382-010-0783-5

Harris, I. P. D. J., Jones, P. D., Osborn, T. J., and Lister, D. H. (2014). Updated highresolution grids of monthly climatic observations-the CRU TS3. 10 dataset. Int. J. Climatol. 34, 623-642. doi: 10.1002/joc.3711

Harvey, J. E., Smiljaniæ, M., Scharnweber, T., Buras, A., Cedro, A., Cruz-García, R., et al. (2020). Tree growth influenced by warming winter climate and summer moisture availability in northern temperate forests. Glob. Change Biol. 26, 2505-2518. doi: 10.1111/gcb.14966

Havranek, W. M., and Tranquillini, W. (1995). "Physiological processes during winter dormancy and their ecological significance," in Ecophysiology of Coniferous Forests, eds W. K. Smith, and T. H. Hinckley (Cambridge, MA: Academic Press), 95-124. doi: 10.1016/B978-0-08-092593-6.50010-4

Helama, S., and Lindholm, M. (2003). Droughts and rainfall in south-eastern Finland since $\mathrm{AD}$ 874, inferred from Scots pine ring-widths. Boreal Environ. Res. 8, 171-183.

Helama, S., Lindholm, M., Timonen, M., and Eronen, M. (2004). Detection of climate signal in dendrochronological data analysis: a comparison of tree-ring standardization methods. Theor. Appl. Climatol. 79, 239-254. doi: 10.1007/ s00704-004-0077-0

HELCOM (2013). Climate change in the Baltic sea area: HELCOM thematic assessment in 2013. Baltic Sea Environ. Proc. 137, 1-53.

Herrero, A., Rigling, A., and Zamora, R. (2013). Varying climate sensitivity at the dry distribution edge of Pinus sylvestris and P. nigra. For. Ecol. Manag. 308, 50-61. doi: 10.1016/j.foreco.2013.07.034

Holmes, R. (1985). Computer-assisted quality control in tree-ring dating and measurement: a user's manual for program COFECHA. Tree Ring Bull. 43, 51-67.

Hordo, M., Henttonen, H. M., Mäkinen, H., Helama, S., and Kiviste, A. (2011). Annual growth variation of Scots pine in Estonia and Finland. Baltic For. 17, 35-49.

Hordo, M., Metslaid, S., and Kiviste, A. (2009). Response of Scots pine (Pinus sylvestris L.) radial growth to climate factors in Estonia. Baltic For. 15, 195-205.

Jaagus, J. (2006). Climatic changes in Estonia during the second half of the 20th century in relationship with changes in large-scale atmospheric circulation. Theor. Appl. Climatol. 83, 77-88. doi: 10.1007/s00704-005-0161-0

Janecka, K., and Kaczka, R. J. (2016). Wpływ wystêpowania drewna kompresyjnego na dekoncentrycznośæ szerokości przyrostów i sygnał klimatyczny w świerku pospolitym z regla dolnego w Tatrach Zachodnich. Studia i Materialy Centrum Edukacji Przyrodniczo-Leśnej 18, 48.

Janecka, K., Kaczka, R. J., Gärtner, H., Harvey, J. E., and Treydte, K. (2020). Compression wood has a minor effect on the climate signal in tree-ring stable isotope records of montane Norway spruce. Tree Physiol. 40, 1014-1028. doi: 10.1093/treephys/tpaa038

Janecka, K., Kaczka, R. J., Gärtner, H., and Treydte, K. (2016). “The influence of compression wood on the strength of the climatic signal in tree rings of Norway spruce," in TRACE-Tree Rings in Archaeology, Climatology and Ecology, eds A. Hevia, R. Sánchez-Salguero, J. C. Linares, J. M. Olano, J. J. Camarero, E. Gutiérrez, et al. (Lund sweden: TRACE), 50-59.

Jönsson, K., and Nilsson, C. (2009). Scots pine (Pinus sylvestris L.) on shingle fields: a dendrochronologic reconstruction of early summer precipitation in Mideast Sweden. J. Clim. 22, 4710-4722. doi: 10.1175/2009JCLI2401.1

Kaczka, R. J., Spyt, B., Janecka, K., Beil, I., Büntgen, U., Scharnweber, T., et al. (2018). Different maximum latewood density and blue intensity measurements techniques reveal similar results. Dendrochronologia 49, 94-101. doi: 10.1016/j. dendro.2018.03.005

Kaczka, R. J., Spyt, B., Janecka, K., Niedźwiedź, T., and Bednarz, Z. (2016). “Climate reconstruction from tree-rings in the Tatra mountains," in Flood Risk in the Upper Vistula Basin, eds Z. Kundzewicz, M. Stoffel, T. Niedźwiedź, B. Wyżga (Cham: Springer), 209-229. doi: 10.1007/978-3-319-41923-7_10
Koprowski, M. (2013). Spatial distribution of introduced Norway spruce growth in lowland Poland: the influence of changing climate and extreme weather events. Quatern. Int. 283, 139-146. doi: 10.1016/j.quaint.2012.04.020

Koprowski, M., Winchester, V., and Zielski, A. (2010). Tree reactions and dune movements: slowinski National Park, Poland. Catena 81, 55-65. doi: 10.1016/j. catena.2010.01.004

Kozuchowski, K., and Degirmendzic, J. (2005). Contemporary changes of climate in Poland: trends and variation in thermal and solar conditions related to plant vegetation. Polish J. Ecol. 53, 283-297.

Kreyling, J. (2010). Winter climate change: a critical factor for temperate vegetation performance. Ecology 91, 1939-1948. doi: 10.1890/09-1160.1

Łabuz, T. A. (2013). Polish coastal dunes: affecting factors and morphology. Landform Anal. 22, 33-59. doi: 10.12657/landfana.022.004

Lange, J., Buras, A., Cruz-García, R., Gurskaya, M., Jalkanen, R., Kukarskih, V., et al. (2018). Climate regimes override micro-site effects on the summer temperature signal of Scots pine at its northern distribution limits. Front. Plant Sci. 9:1597. doi: 10.3389/fpls.2018.01597

Larsson, L. A. (2003). CDendro: Cybis Dendro Dating Program. Saltsjöbaden: Cybis Elektronik \& Data AB.

Lefcheck, J. S. (2016). piecewiseSEM: piecewise structural equation modelling in $r$ for ecology, evolution, and systematics. Methods Ecol. Evol. 7, 573-579. doi: 10.1111/2041-210X.12512

Linderholm, H. W., and Chen, D. (2005). Central Scandinavian winter precipitation variability during the past five centuries reconstructed from Pinus sylvestris tree rings. Boreas 34, 43-52. doi: 10.1111/j.1502-3885.2005.tb01003.x

Linderholm, H. W., Zhang, P., Gunnarson, B. E., Björklund, J., Farahat, E., Fuentes, M., et al. (2014). Growth dynamics of tree-line and lake-shore Scots pine (Pinus sylvestris L.) in the central Scandinavian mountains during the medieval climate anomaly and the early little ice age. Front. Ecol. Evol. 2:303. doi: 10.3389/fevo. 2014.00020

Lindholm, M., Meriläinen, J., Timonen, M., Vanninen, P., and Eronen, M. (1997). Effects of climate on the growth of Scots pine in the Saimaa lake district, south-eastern Finland, in the southern part of the boreal forest belt. Dendrochronologia 15, 151-168.

Lindholm, M., Ogurtsov, M. G., Jalkanen, R., Gunnarson, B. E., and Aalto, T. (2014). Six temperature proxies of Scots pine from the interior of northern Fennoscandia combined in three frequency ranges. J. Climatol. 2014, 1-13. doi: $10.1155 / 2014 / 578761$

Lindner, M., Maroschek, M., Netherer, S., Kremer, A., Barbati, A., Garcia-Gonzalo, J., et al. (2010). Climate change impacts, adaptive capacity, and vulnerability of European forest ecosystems. Forest Ecol. Manag. 259, 698-709. doi: 10.1016/j. foreco.2009.09.023

Mandre, M., Kõresaar, K., and Kõresaar, P. (2008). Mineral nutrition of natural regeneration of Scots pine on coastal dunes in South-West Estonia. Estonian J. Ecol. 57, 70-80. doi: 10.3176/eco.2008.1.05

Mandre, M., Lukjanova, A., Pärn, H., and Kõresaar, K. (2010). State of Scots pine (Pinus sylvestris L.) under nutrient and water deficit on coastal dunes of the Baltic Sea. Trees 24, 1073-1085. doi: 10.1007/s00468-010-0479-9

Matisons, R., Jansone, D., Elferts, D., Adamovičs, A., Schneck, V., and Jansons, A (2019). Plasticity of response of ring-width of Scots pine provenances to weather extremes in Latvia. Dendrochronologia 54, 1-10. doi: 10.1016/j.dendro.2019. 01.002

Matulewski, P., Buchwal, A., and Makohonienko, M. (2019). Higher climatic sensitivity of Scots pine (Pinus sylvestris L.) subjected to tourist pressure on a hiking trail in the Brodnica Lakeland, NE Poland. Dendrochronologia 54, 78-86. doi: 10.1016/j.dendro.2019.02.008

Maun, A. (2009). The Biology of Coastal Sand Dunes. Oxford: Oxford University Press.

Mazza, G., and Manetti, M. C. (2013). Growth rate and climate responses of Pinus pinea L. in Italian coastal stands over the last century. Clim. Change 121, 713-725. doi: 10.1007/s10584-013-0933-y

McCarroll, D., Pettigrew, E., Luckman, A., Guibal, F., and Edouard, J. L. (2002). Blue reflectance provides a surrogate for latewood density of high-latitude pine tree rings. Arctic Antarctic Alpine Res. 34, 450-453. doi: 10.1080/15230430.2002. 12003516

McCarthy, J. J., Canziani, O. F., Leary, N. A., Dokken, D. J., and White, K. S. (2001). Climate Change 2001: Impacts, Adaptation, and Vulnerability: Contribution of 
Working Group II to The Third Assessment Report of the Intergovernmental Panel on Climate Change. Cambridge, MA: Cambridge University Press.

Metslaid, S., Hordo, M., Korjus, H., Kiviste, A., and Kangur, A. (2018). Spatiotemporal variability in Scots pine radial growth responses to annual climate fluctuations in hemiboreal forests of Estonia. Agric. For. Meteorol. 252, 283-295. doi: 10.1016/j.agrformet.2018.01.018

Metslaid, S., Stanturf, J. A., Hordo, M., Korjus, H., Laarmann, D., and Kiviste, A. (2016). Growth responses of Scots pine to climatic factors on reclaimed oil shale mined land. Environ. Sci. Pollut. Res. 23, 13637-13652. doi: 10.1007/s11356015-5647-4

Mikkonen, S., Laine, M., Mäkelä, H. M., Gregow, H., Tuomenvirta, H., Lahtinen, M., et al. (2015). Trends in the average temperature in Finland, 1847-2013. Stochastic Environ. Res. Risk Assess. 29, 1521-1529. doi: 10.1007/s00477-0140992-2

Misi, D., and Nafradi, K. (2016). Late winter-Early spring thermal conditions and their long-term effect on tree-ring growth in Hungary. Balt. For. 22, 203-211.

Murtagh, F., and Legendre, P. (2014). Ward's hierarchical agglomerative clustering method: which algorithms implement Ward's criterion? J. Classif. 31, 274-295. doi: 10.1007/s00357-014-9161-z

Nakagawa, S., and Schielzeth, H. (2013). A general and simple method for obtaining R2 from generalized linear mixed-effects models. Methods Ecol. Evol. 4, 133-142. doi: 10.1111/j.2041-210x.2012.00261.x

Neumann, T. (2010). Climate-change effects on the Baltic Sea ecosystem: a model study. J. Mar. Syst. 8, 213-224. doi: 10.1016/j.jmarsys.2009.12.001

Niklasson, M. (2015). Skogshistoria och bränder på Gotska Sandön. - Rapporter om natur och miljö nr 2015:1. Visby: Länsstyrelsen I Gotlands Län.

Örd, A. (1972). Edela-Eesti luitemetsade mullastikust. Metsanduslikud Uurim 9, 207-221.

Pärn, H. (2002). Growth of Scots pine (Pinus sylvestris) on dunes of Southwest Estonia related to climate. For. Stud. 39, 65-80.

Pärn, H. (2008). Influence of the stand position on the slope and climate on latewood characteristics of Scots pine on dunes of South-West Estonia. For. Stud. 49, 13-24. doi: 10.2478/v10132-011-0059-9

Pärn, H. (2009). Temporal history of relationships between Scots pine (Pinus sylvestris L.) radial growth and mean monthly temperatures. Baltic For. 15, 48-57.

Parry, M., Parry, M. L., Canziani, O., Palutikof, J., Van der Linden, P., and Hanson, C. (2007). Climate Change 2007-Impacts, Adaptation and Vulnerability: Working Group II Contribution to the Fourth Assessment Report of the IPCC, Vol. 4. Cambridge, MA: Cambridge University Press.

Pederson, N., Leland, C., Bishop, D. A., Pearl, J. K., Anchukaitis, K. J., Mandra, T., et al. (2020). A framework for determining population-level vulnerability to climate: evidence for growth hysteresis in Chamaecyparis thyoides along its contiguous latitudinal distribution. Front. For. Glob. Change 3:39. doi: 10.3389/ ffgc.2020.00039

Peterson, D. W., and Peterson, D. L. (2001). Mountain hemlock growth responds to climatic variability at annual and decadal time scales. Ecology 82, 3330-3345. doi: 10.1890/0012-9658(2001)082[3330:mhgrtc] 2.0.co;2

Pretzsch, H. (2009). Forest Dynamics, Growth, and Yield in Forest Dynamics, Growth and Yield. Berlin: Springer, 1-39. doi: 10.1007/978-3-54088307-4_1

R core team (2018). R: A Language And Environment for Statistical Computing. Vienna: R Foundation for Statistical Computing.

Räisänen, J., and Alexandersson, H. (2003). A probabilistic view on recent and near future climate change in Sweden. Tellus A 55, 113-125. doi: 10.3402/tellusa. v55i2.12089

Ratas, U., and Rivis, R. (2003). Coastal dune landscape of Estonia. For. Stud. 39, 9-19.

Rigling, A., Waldner, P. O., Forster, T., Bräker, O. U., and Pouttu, A. (2001). Ecological interpretation of tree-ring-width and intraannual density fluctuations in Pinus sylvestris on dry sites in the central Alps and Siberia. Can. J. For. Res. 31, 18-31. doi: 10.1139/x00-126

Ryan, M. G., Phillips, N., and Bond, B. J. (2006). The hydraulic limitation hypothesis revisited. Plant Cell Environ. 29, 367-381. doi: 10.1111/j.1365-3040. 2005.01478.x

Rydval, M., Larsson, L. Å, McGlynn, L., Gunnarson, B. E., Loader, N. J., Young, G. H., et al. (2014). Blue intensity for dendroclimatology: should we have the blues? Experiments from Scotland. Dendrochronologia 32, 191-204. doi: 10.1016/j.dendro.2014.04.003

Sánchez-Salguero, R., Camarero, J. J., Hevia, A., Madrigal-González, J., and Linares, J. C. (2015a). What drives growth of Scots pine in continental Mediterranean climates: drought, low temperatures or both? Agric. For. Meteorol. 206, 151-162. doi: 10.1016/j.agrformet.2015.03.004

Sánchez-Salguero, R., Linares, J. C., Camarero, J. J., Madrigal-González, J., Hevia, A., Sánchez-Miranda, Á, et al. (2015b). Disentangling the effects of competition and climate on individual tree growth: a retrospective and dynamic approach in Scots pine. For. Ecol. Manag. 358, 12-25. doi: 10.1016/j.foreco.2015. 08.034

Schweingruber, F. H. (2012). Tree Rings: Basics and Applications of Dendrochronology. Cham: Springer.

Schweingruber, F. H., Bartholin, T., Schaur, E., and Briffa, K. R. (1988). Radiodensitometric-dendroclimatological conifer chronologies from Lapland (Scandinavia) and the Alps (Switzerland). Boreas 17, 559-566. doi: 10.1111/j. 1502-3885.1988.tb00569.x

Seftigen, K., Fuentes, M., Ljungqvist, F. C., and Björklund, J. (2020). Using Blue Intensity from drought-sensitive Pinus sylvestris in Fennoscandia to improve reconstruction of past hydroclimate variability. Clim. Dyn. 55, 579-594. doi: 10.1007/s00382-020-05287-2

Seftigen, K., Linderholm, H. W., Drobyshev, I., and Niklasson, M. (2013). Reconstructed drought variability in southeastern Sweden since the 1650s. Int. J. Climatol. 33, 2449-2458. doi: 10.1002/joc.3592

Sevanto, S., Suni, T., Pumpanen, J., Grönholm, T., Kolari, P., Nikinmaa, E., et al. (2006). Wintertime photosynthesis and water uptake in a boreal forest. Tree Physiol. 26, 749-757. doi: 10.1093/treephys/26.6.749

Speer, J. H. (2010). Fundamentals of Tree-Ring Research. University of Arizona Press.

Trouet, V., and van Oldenborgh, G. J. (2013). KNMI Climate Explorer: a webbased research tool for high-resolution paleoclimatology. Tree Ring Res. 69, 3-13. doi: 10.3959/1536-1098-69.1.3

Trouillier, M., van der Maaten-Theunissen, M., Scharnweber, T., Würth, D., Burger, A., Schnittler, M., et al. (2019). Size matters-a comparison of three methods to assess age-and size-dependent climate sensitivity of trees. Trees 33 , 183-192. doi: 10.1007/s00468-018-1767-z

van Oldenborgh, G. J., and Burgers, G. (2005). Searching for decadal variations in ENSO precipitation teleconnections. Geophys. Res. Lett. 32, 1-5. doi: 10.1029/ 2005GL023110

Vidgen, B., and Yasseri, T. (2016). P-values: misunderstood and misused. Front. Phys. 4:6. doi: 10.3389/fphy.2016.00006

Vitas, A. (2004). Dendroclimatological research of Scots pine (Pinus sylvestris L.) in the Baltic coastal zone of Lithuania. Baltic For. 10, 65-71.

Vitas, A. (2006). Sensitivity of Scots pine trees to winter colds and summer droughts: dendroclimatological investigation. Baltic For. 12, 220-226.

Vitas, A., and Bitvinskas, T. (1998). Dendroclimatological similarities of Picea abies (L.) Karsten and Pinus sylvestris (L.). Baltic For. 4, 24-28.

Vitas, A., and Erlickyte, R. (2007). Influence of droughts to the radial growth of Scots pine (Pinus sylvestris L.) at different site conditions. Baltic Forestry 13, $10-16$.

von Storch, H., Omstedt, A., Pawlak, J., and Reckermann, M. (2015). Introduction and Summary in, the BACC II Author Team in: Second Assessment of Climate Change for the Baltic Sea Basin. Cham: Springer International Publishing, 1-22. doi: 10.1007/978-3-319-16006-1_1

Wei, T., Simko, V., Levy, M., Xie, Y., Jin, Y., and Zemla, J. (2017). Package 'corrplot'. Statistician 56, 316-324.

Wigley, T. M., Briffa, K. R., and Jones, P. D. (1984). On the average value of correlated time series, with applications in dendroclimatology and hydrometeorology. J. Clim. Appl. Meteorol. 23, 201-213. doi: 10.1175/15200450(1984)023<0201:otavoc > 2.0.co;2

Wilson, R., Anchukaitis, K., Briffa, K. R., Büntgen, U., Cook, E., D’arrigo, R., et al. (2016). Last millennium northern hemisphere summer temperatures from tree rings: Part I: the long term context. Quatern. Sci. Rev. 134, 1-18. doi: 10.1016/j. quascirev.2015.12.005

Wilson, R., D’Arrigo, R., Andreu-Hayles, L., Oelkers, R., Wiles, G., Anchukaitis, K., et al. (2017). Experiments based on blue intensity for reconstructing North Pacific temperatures along the Gulf of Alaska. Clim. Past 13, 1007-1022. doi: $10.5194 /$ cp-13-1007-2017 
Wilson, R., Rao, R., Rydval, M., Wood, C., Larsson, L. Å, and Luckman, B. H. (2014). Blue Intensity for dendroclimatology: the BC blues: a case study from British Columbia, Canada. Holocene 24, 1428-1438. doi: 10.1177/ 0959683614544051

Zang, C., and Biondi, F. (2015). treeclim: an R package for the numerical calibration of proxy-climate relationships. Ecography 38, 431-436. doi: 10.1111/ecog.01335

Zeng, Q., Rossi, S., and Yang, B. (2018). Effects of age and size on xylem phenology in two conifers of Northwestern China. Front. Plant Sci. 8:2264. doi: 10.3389/ fpls.2017.02264

Zuur, A., Ieno, E. N., Walker, N., Saveliev, A. A., and Smith, G. M. (2009). Mixed Effects Models and Extensions in Ecology with R. Berlin: Springer. doi: 10.1007/ 978-0-387-87458-6
Conflict of Interest: The authors declare that the research was conducted in the absence of any commercial or financial relationships that could be construed as a potential conflict of interest.

Copyright (อ 2020 Janecka, Harvey, Trouillier, Kaczka, Metslaid, Metslaid, Buras and Wilmking. This is an open-access article distributed under the terms of the Creative Commons Attribution License (CC BY). The use, distribution or reproduction in other forums is permitted, provided the original author(s) and the copyright owner(s) are credited and that the original publication in this journal is cited, in accordance with accepted academic practice. No use, distribution or reproduction is permitted which does not comply with these terms. 